\title{
Money and modernization in early modern England
}

DOI:

10.1017/s0968565018000185

\section{Document Version}

Accepted author manuscript

Link to publication record in Manchester Research Explorer

\section{Citation for published version (APA):}

Palma, N. (2019). Money and modernization in early modern England. Financial History Review, 25(3), 231-261. https://doi.org/10.1017/s0968565018000185

\section{Published in:}

Financial History Review

\section{Citing this paper}

Please note that where the full-text provided on Manchester Research Explorer is the Author Accepted Manuscript or Proof version this may differ from the final Published version. If citing, it is advised that you check and use the publisher's definitive version.

\section{General rights}

Copyright and moral rights for the publications made accessible in the Research Explorer are retained by the authors and/or other copyright owners and it is a condition of accessing publications that users recognise and abide by the legal requirements associated with these rights.

\section{Takedown policy}

If you believe that this document breaches copyright please refer to the University of Manchester's Takedown Procedures [http://man.ac.uk/04Y6Bo] or contact uml.scholarlycommunications@manchester.ac.uk providing relevant details, so we can investigate your claim.

\section{OPEN ACCESS}




\title{
MONEY AND MODERNIZATION IN EARLY MODERN ENGLAND ${ }^{1}$
}

\author{
Nuno Palma \\ University of Manchester and CEPR
}

Forthcoming, Financial History Review

\footnotetext{
1 I am thankful to Martin Allen, Edward Besly, Bruce Campbell, Rui Pedro Esteves, Regina Grafe, Nick Mayhew, Larry Neal, Judy Stephenson, and Jan Luiten van Zanden for helpful discussions. Special thanks to the FHR editor, Stefano Battilossi, for detailed comments which led to significant improvements. Adam Brzezinski provided excellent research assistance. The usual disclaimer applies. An earlier version of this paper circulated as the EUI working paper MWP 2016/11 under the title "Money and modernization: liquidity, specialization, and structural change in early modern England".
} 


\begin{abstract}
Classic accounts of the English industrial revolution present a long period of stagnation followed by a fast take-off. However, recent findings of slow but steady per capita economic growth suggest that this is a historically inaccurate portrait of early modern England. This growth pattern was in part driven by specialization and structural change accompanied by an increase in market participation at both the intensive and extensive levels. These, I argue, were supported by the gradual increase in money supply made possible by the importation of precious metals from America. They allowed for a substantial increase in the monetization and liquidity levels of the economy, hence decreasing transaction costs, increasing market thickness, changing the relative incentive for participating in the market, and allowing for agglomeration economies. By making trade with Asia possible, precious metals also induced demand for new desirable goods, which in turn encouraged market participation. Finally, the increased monetization and market participation made tax collection easier. This helped the government to build up fiscal capacity and as a consequence to provide for public goods. The structural change and increased market participation that ensued paved the way to modernization.
\end{abstract}

\title{
Keywords
}

Origins and persistence of modern economic growth; the industrious, industrial and financial revolutions; early modern monetary injections; the great divergence; the little divergence; state-formation; provision of public goods.

JEL codes: E10, E40, E50, N13, N33, O40 
The modernization of early modern England was facilitated by large-scale monetary injections which resulted from the discovery of precious metals in America. These injections interacted positively with certain characteristics of the Northwestern European economies. In this paper, I explain how the increased monetization and liquidity made possible by the arrival of precious metals from America buttressed early growth patterns in England.

Figure 1 illustrates the scale of the English monetary injection in aggregate terms. ${ }^{2}$ The figure shows that prices simply failed to keep up with the enormous increase in per capita coin supply. ${ }^{3}$ The long-run evidence for England clearly contradicts a quantity-theory interpretation of the evolution of prices over the long run. The nominal coin stock increased by a factor of 22 , from about $£^{2}$ million in 1550 to $£^{44}$ million by 1790 , but the price level failed to keep up with even such a narrow measure of the money supply, having less than tripled over the same period. Consequently, real coin supply per capita increased from $£^{1-1.5}$ in the 1550 s to nearly $£ 5$ by the early 1790 s (at constant prices of 1700 ).

The increased monetization of the English economy combined with other historical developments over the early modern period to decrease the cost of participating in markets. This in turn led to more specialization through division of labor, and to labor expansion on the intensive and extensive margins. The greater ease in making and receiving payments meant that it becameeasier for firms to pay the wage bill and for

\footnotetext{
2 I take this opportunity to do a small correction to Palma (2018), explained in the Appendix.

${ }^{3}$ Using instead the retail price index of Clark (2018) would lead to the same conclusion.
} 
people to work additional days - one feature of the early modern industrious revolution. ${ }^{4}$

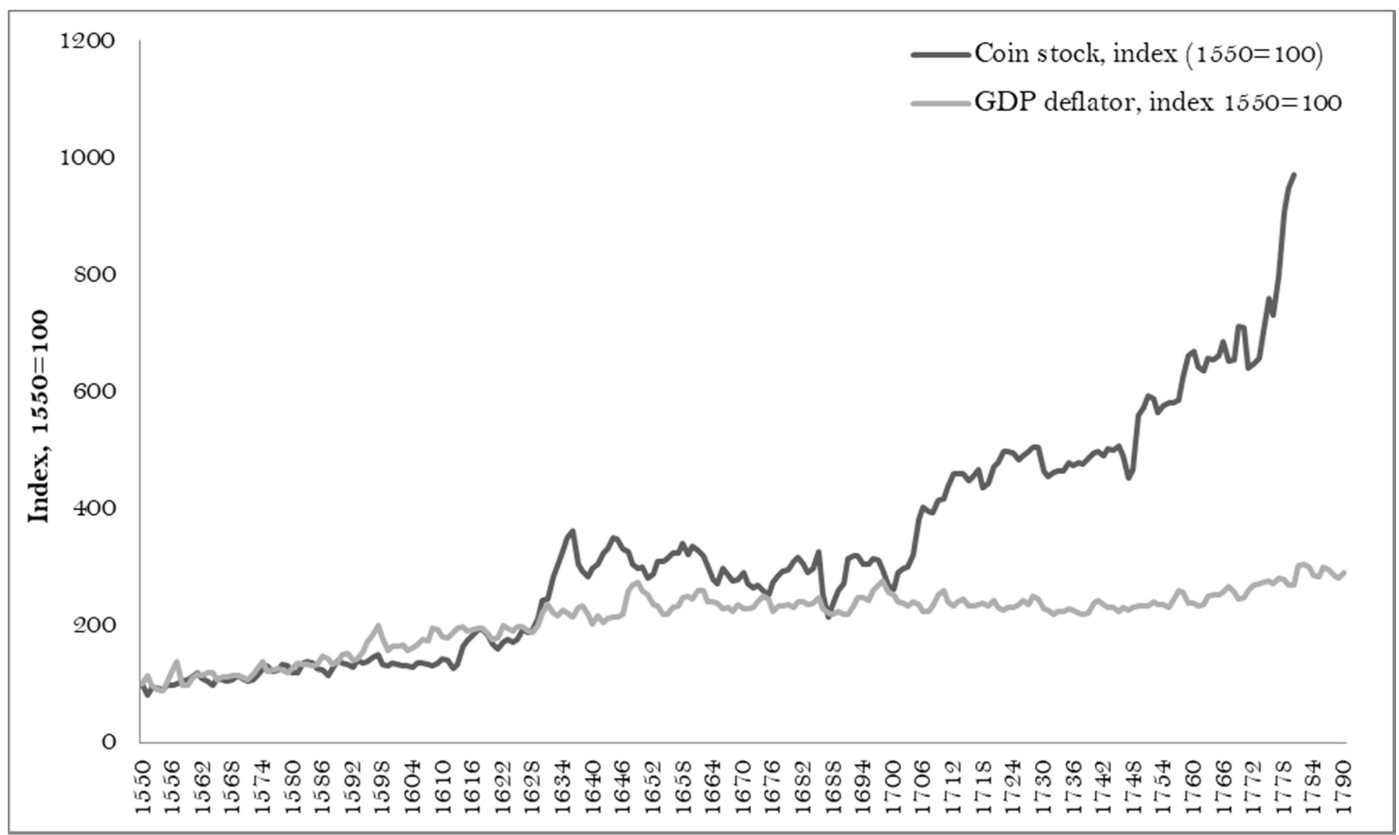

Figure 1. Coin supply and price level, 1550-1790. Source: coin supply adjusted from Palma (2018); the price level is the GDP deflator of Broadberry et al (2015).

Why was expanding the money supply historically difficult? The early modern monetary system was a commodity money system. ${ }^{5}$ In this system, monetary authorities had only two ways of expanding the official (legal tender) money supply, which during the early modern period was by far the most important component of high-powered money supply (Mo). The first was to debase the currency. ${ }^{6}$ This policy tool was constrained by the

\footnotetext{
${ }^{4}$ My contribution to the study of the industrious revolution aims to complement the standard reasons given in the literature (e.g. demand for new goods deVries 1994, 2009) by pointing out that there was a complementary monetary element. Indeed, many of the new goods which led to an increased labor supply depended on the availability of precious metals to be imported from Asia (Palma and Silva 2016).

${ }^{5}$ Other assets which functioned as means of exchange (inside money) did at times develop. I argue that the two forms were rather complements than substitutes. The discussion in the present section is initially restricted to outside money, but other forms of money will be considered below.

${ }^{6}$ Munro (2011) makes a helpful distinction between aggressive and defensive coinage debasements. The former were fiscally-motivated. The latter were a response to the debasements of neighborhood
} 
equilibrium responses of private agents to mint policy, as well as competition with foreign mints (Sargent and Velde 2002). The only remaining possibility was to have access to new sources of bullion, either through mining or trade, as this was the critical input in the production of specie. ${ }^{7}$ Monetary policy was conducted by means of the monetary authority setting the mint price at which private agents could coin currency from bullion, after payment of a seigniorage fee. For this, precious metals needed to be available.

As the major input in the production of specie was bullion, and since the latter was offered in inelastic supply, money supply was inelastic as well. The limited availability of preciousmetals meant that mint policies were restricted by the equilibrium in the international bullion market. Furthermore, each coin's face value had a larger value than that of the market value of its metal content, because of the extra exchange service that each coin provided. Assaying costs were also relatively higher for smaller denominations. These restrictions, together with the indivisibility problem generated by the physical properties of commodity money (discussed in Section II), constrained the issue of low denomination specie.

Taken together, these restrictions lead to a higher bound in the effective money that could be supplied by a monetary authority at a given moment, indexed by the availability of precious metals. From the mid-15th century to about 1520, the exploration of the West African coast by the Portuguese brought to Europe gold at a lower cost than had been previously possible with the trans-Saharan caravan trade. This can reasonably be (Contd.) lands, and additionally a necessary consequence of the fact that where coins circulated by tale, longterm "wear and tear", clipping, sweating, and counterfeiting diminished the average content of precious metals in the coinage over time.

${ }^{7}$ Indeed, "British currency was convertible at fixed rates into silver and gold. It exchanged at virtually fixed rates for other currencies similarly convertible. Hence the value of money in England must have been largely determined by the supply of the precious metals, and the demand for these, in the whole group of nations linked in this way" (Ashton 1972, p.196) 
described as an endogenous development and it is hard to say if the increase in supply through this means was not offset by relative decline in the North African caravan route. These gold injections were also of moderate quantities when measured at a European level. During the early fifteenth century there was also increasing production of silver in Burgundy, Saxony and Bohemia and associated technical change made silver available at a lower cost than had been previously possible (Cipolla 1993, p.174-5). But duringthe early modern period, Europe experienced monetary injections of unprecedented magnitude.

The availability of great quantities of precious metals in America was critical in allowing the European money supply to expand as it did in the early modern period. In their counterfactual absence, forms of "inside" money including fiat, bank deposits, bills of exchange or other forms of credit could not have compensated for the relative decrease in coin supply anywhere in Europe before $1790 .{ }^{8}$ The decrease in transaction costs encouraged people who were not already involved in the formal market economy - or were only marginally so in rural areas - to become involved, both while staying in the countryside, and, importantly, by moving to cities, hence contributing to structural change and agglomeration returns.

In England about 40 percent of households lived mainly on wages in 1524-5, a ratio which had been approximately constant since the thirteenth century (Dyer 2002, p. 364). ${ }^{9}$ But by the early 1780 s few people were not directly involved in the cash

\footnotetext{
${ }^{8}$ In fact, those higher forms of money would have decreased. This is because the relationship between them and coin was analogous to a traditional multiplier effect on base or high-powered money (Mo). This will be discussed in detail in section II.

9 The situation in the early sixteenth century corresponded to a long-term stagnation which only American precious metals would break. Indeed, “[i] n 1300 ... wage labor may have accounted for about a fifth to a quarter of the total labour expended in producing goods and services. In this respect, however, the world did not change in the direction of capitalism between 1300 and 1525 " (Britnell 1993, p. 364; see also Britnell 2009). There was also room for expansion for those only occasionally involved with cash: "by the fourteenth century ... in the most advanced areas of Europe about half of the adult population was involved and familiar with wage labour. However, because
} 
economy (Porter 1990, p. 187). I argue that this would have not been possible without the enormous increase in money supply. In this paper I document the large-scale increase in the availability of precious metals which followed from the discovery of America, and consider in detail its effects for the English economy. I discuss a variety of channels through which it affected economic growth and modernization. I also present some comparative remarks on the effects on the continental economies.

The very large monetary injections that were the result of the discovery of America, I argue, mattered a great deal in making the English industrious and industrial revolutions possible, by alleviating the restrictions imposed on money supply by the availability of precious metals. In order for my argument to be valid, two conditions were necessary: First, it must be that money (or its substitutes) would not have expanded anyway, even if precious metals in America were not available. Second, it must be that modernization would not have happened anyway, had the money supply not expanded. That is, monetization must have had a causal effect for modernization. ${ }^{10}$ I now consider the first of these conditions in Section II, and in Section III, I address the second. Then in section IV, I show that the English economy became deeply monetized during the early modern period. In section V, I conclude.

(Contd.)

labor was seasonal, especially in rural areas, the share of the adult population in permanent wage labour was smaller. Rural wage labour was concentrated on peaks in the agricultural cycle, such as harvest work by cottagers and land-less workers" (Persson and Sharp 2015, p. 97).

10 The money-growth causality went both ways. The English economy had the right conditions to grow and demanded additional means of exchange (McCloskey and Zecher 1974). But my emphasis on the role of American precious metals is that they were necessary for monetization to increase, which in turn was necessary (but not sufficient) for economic growth to occur. 


\section{II}

There are three reasons why money or credit would not have expanded anyway, without the injections of precious metals from America. First, there are constraints on the power of debasement policies and how small denominations can become. Second, due to credibility problems, higher forms of money (e.g. government-supplied paper) were not a feasible alternative to coin supply at that time. And third, inside money (most credit) was a complement, not a substitute, to coin in early modern England. These reasons are discussed in turn below.

The first alternative way to expand the money supply that I consider was the use of debasements. In principle, debasements do not require access to new metal sources. However, there are multiple problems with this policy. First, debasements could be politically unpopular. Second, if the currency was too debased, people would use foreign currency, and governments' seigniorage revenue would diminish. In addition, systematic debasements could lead to a denominational problem related to the physical property of currency as an object to facilitate exchange and liquidity - namely, either the alloy with intrinsic value would become too small relative to the overall size and weight of the coin, making it difficult to verify, or small denomination coins would become too small to be practical. Finally, additional problems with debasements were their effects on the amount of money in circulation and the price level. As Redish (1990, p. 795) writes, "The political unpopularity of calling down the money and the costs of reminting meant that the adjustment was most frequently made by calling up the undervalued coin. If this were done on an annual basis to correct the coin ratings, however, the currency would have a persistent tendency to depreciate - that is, for the amount of specie per unit of account to decrease." 
Irrespective of the matters of strategic considerations related to competition with foreign mints, debasements had limits. If economic growth was taking place but the supply of precious metals was not increasing, there was only one way to keep a given denomination proportional to other denominations in relative weight of precious metal content, which was to make the smaller denominations quite small in physical size. ${ }^{11}$ Doing so had obvious disadvantages to trade, and further made assaying harder, amplifying the uncertainty of accepting any given coin in a random and non-repeatable transaction where reputation was not relevant. ${ }^{12}$ It also amplified the "big problem of small change" (Sargent and Velde 2002), since smaller denominations became even more liquid relative to their value.

Despite these disadvantages, the policy of introducing small change was nevertheless sometimes attempted. For instance, a quarter-guinea coin weighing 2.09 grams was launched in 1718 , but failed: "A piece so tiny, and so readily lost, was entirely unacceptable to the British public" (Craig 2011, p.21). Nevertheless, the need for credible small change to support trade was pressing enough that it led essayists in mid-eighteenth century England to continue recommending the minting of this coin (Redish 1990).

Constrained by the limits of debasement as a policy tool, states were limited to finding new sources of precious metals if they wished to expand money supply while maintaining

11 This problem is even more serious for gold than silver, yet silver suffered from the opposite problem; valued by weight coins could become too large and cumbersome to carry (Redish 1990, p.792). This is what disqualified copper from serving as anything other than a token currency.

12 The relative weight of precious metals could not get too small as a percentage of the overall weight of the coin, otherwise it would become difficult to assay (and less worthwhile to pay the fixed costs of doing so). 
convertibility. ${ }^{13}$ The good fortune of the early modern precious metals discoveries is that they alleviated these problems.

A second reason money supply might have increased even without the appearance of precious metals is that, in principle, higher forms of money could have made specie less necessary. However, it is important not to exaggerate the relevance of inside money during the early modern period. Paper money only became prevalent in Europe in the nineteenth century. ${ }^{14}$ In England, as late as 1790, the monetary base was composed of $£ 44$ million of commodity-based coin and only $£ 12$ million in notes ( 8 million of Bank of England notes and $£ 4$ million of all other notes; Capie 2004; Table 1).

The timing of the growth of fiat and other means of payment can be contrasted with that for the size of government. One of the most remarkable aspects of the evolution of the English economy since the mid-seventeenth century was the persistent growth of the government sector, which accelerated during the eighteenth century, more than quadrupling between 1700 and 1790. The growth of government happened through a ratchet effect, with expansion during times of war not fully reversed when peace came along (Brewer 1989, O’Brien 1988).

\footnotetext{
${ }^{13}$ Convertibility was inevitable at this time due to commitment problems exemplified by failed attempts such as that of John Law in France.

${ }^{14}$ Scotland did use paper money more regularly than England, but under high transaction costs.
} 


\begin{tabular}{|c|c|c|c|c|c|c|c|}
\hline & $\begin{array}{c}1600 \\
\text { (Mayhew) }\end{array}$ & $\begin{array}{c}1688 \\
\text { (Cameron) }\end{array}$ & $\begin{array}{c}1700 \\
\text { (Capie) }\end{array}$ & $\begin{array}{c}1750 \\
\text { (Cameron) }\end{array}$ & $\begin{array}{c}1750 \\
\text { (Capie) }\end{array}$ & $\begin{array}{c}1790 \\
\text { (Capie) }\end{array}$ & $\begin{array}{c}1870 \\
\text { (Capie) }\end{array}$ \\
\hline Coin & 3.5 & 10 & 7 & 15 & 18 & 44 & 95 \\
\hline $\begin{array}{c}\text { Bank of England } \\
\text { notes }\end{array}$ & - & - & 1.5 & 4.3 & 4 & 8 & 35 \\
\hline $\begin{array}{l}\text { Other notes (country } \\
\text { banknotes) }\end{array}$ & - & - & $\mathrm{O}$ & 0.7 & 1 & 4 & 4.9 \\
\hline $\begin{array}{l}\text { Bank balances at the } \\
\text { bank of England }\end{array}$ & - & - & - & 1.9 & - & - & 6.5 \\
\hline $\begin{array}{l}\text { Other means of } \\
\text { payment }\end{array}$ & 1 & 10 & $\mathrm{n} / \mathrm{a}$ & 18.1 & $\mathrm{n} / \mathrm{a}$ & $\mathrm{n} / \mathrm{a}$ & $\mathrm{n} / \mathrm{a}$ \\
\hline Total (M2) & 4.5 & 20 & $>8.5$ & 40 & $>23$ & $>56$ & $>141.4$ \\
\hline
\end{tabular}

Table 1. Estimates for the components of English nominal money supply. Unit: millions of £. Sources: Mayhew (2013), Capie (2004) and Cameron (1967). The category "other means of payment” includes Cameron's $£ 6$ m in government tallies, $£ 2$ m in inland bills in 1688 , and $£ 3.1 \mathrm{~m}$ in deposits in private banks in 1750 .

This ratchet effect was absent in the case of money supply. This is true for both coin supply and higher forms of money supply, either measured by notes of the bank of England or broader measures that include bills of exchange and notes of provincial banks (Figure 2). The fact that until the last decade of the eighteenth century government expanded in tandem with warfare - but money supply did not - is telling about the fact that in earlier periods the expansion of coin supply was conditional on the availability of precious metals. The bank of England and other financial intermediaries had the capacity to expand higher forms of money, but, concerned with their reputation and solvability, chose not to do so (O'Brien and Palma forthcoming). 


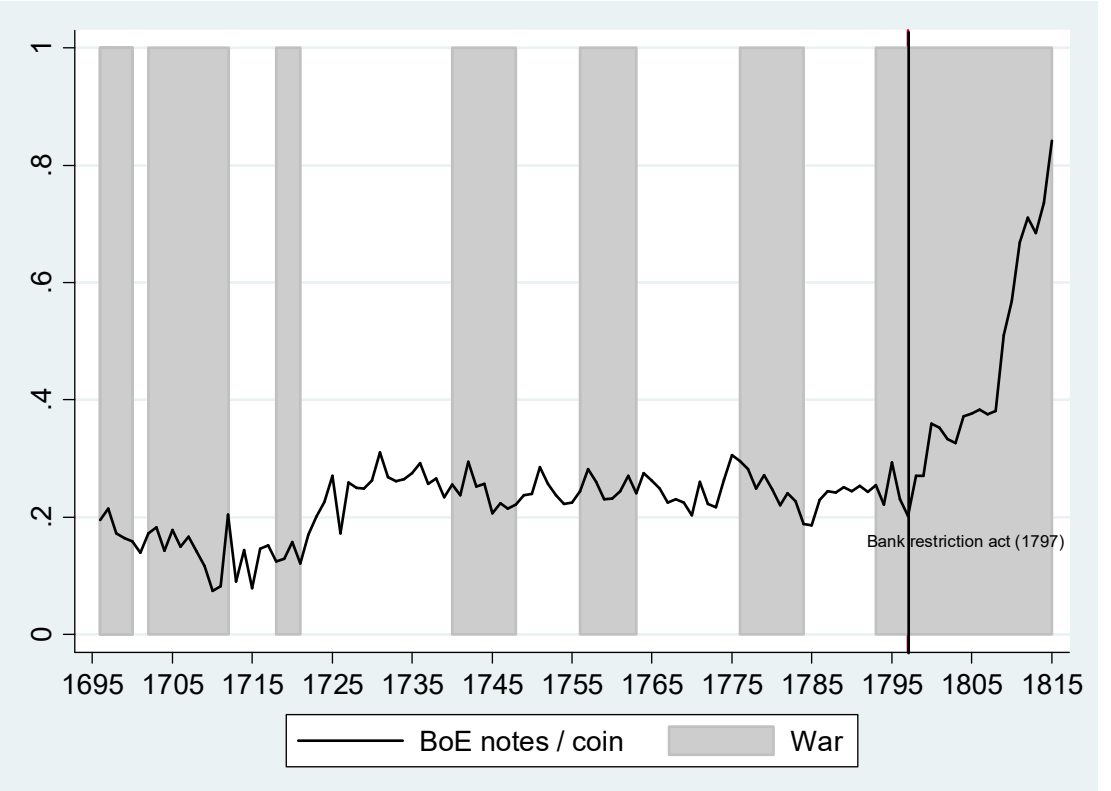

Figure 2. The ratio between Bank of England notes and coin supply, 1694-1815. Sources: Bank of England (1967), O’Brien and Palma (forthcoming).

All notes of the Bank of England (and of provincial banks) were fully convertible until the Act of 1797. Only after that period was it possible for the Bank of England to expand notes significantly without running into credibility problems (Figure 2; O'Brien and Palma forthcoming). The same is true for provincial banks: "the arrival of country banking, combined with the note issues of the Bank of England, was not an answer to the shortage of silver in England and Wales even by the end of the eighteenth century" (Clancy 1999, p.30).

Indeed, Angela Redish plainly states that "it was not possible to establish a stable token coinage prior to the nineteenth century" (Redish 1990). Notes both of the Bank of England and of provincial banks enjoyed limited circulation before the last decade of the century; people did not use these for retail purchases or other regular transactions (Clancy 1999, p. 28-9, Feavearyear 1944, Clapham 1944). According to one estimate by The Board 
of Stamps, as late as 1812-16 the value of country banknotes annually in circulation was under $£ 16$ million (Clancy 1999, p. 29). Finally, it was also the case that until 1793 the lowest denomination for a banknote was $£ 10$, and until 1797 it was $£ 5$, both of which were well above the unskilled weekly wage (Schwarz 1985). Only in 1797 were $£_{2}$ and $£ 1$ notes issued by the Bank, which could be used as a means of exchange at the retail level. As for other English banks, until 1797 all were prohibited from issuing bearer notes of less than $£ 5$ (Feavearyear 1944).

Finally, I argue that coin and credit were complements, not substitutes. It has long been argued that an English "financial revolution" had been in operation at least since the 1660 s (Dickson 1993). This consisted of the increased usage of credit instruments such as bills of exchange and promissory notes, ${ }^{15}$ as well as privately issued tokens, and after 1694, bank notes of the Bank of England (O'Brien and Palma forthcoming) and of provincial banks (Pressnell 1956).

It is true that in the second half of the seventeenth century, the expansion of the English economy was supported by an expansion of credit. But as Table 1 and Figure 3 suggest, by the late seventeenth century M2 (as defined by Palma 2018) was still quite close to coin supply. The seventeenth century's expansion of credit was not sufficient to compensate for the economic growth which was also occurring at both the extensive (population growth) and intensive (per capita) margins. This trend was only reversed in the eighteenth century, in tandem with an increase in the availability of precious metals, due to the discovery of gold in Brazil and to the shifting of mining priorities in the Spanish empire from Peru to Mexico.

15 The Promissory Notes Act of 1704 made all debt instruments negotiable by allowing not just the initial creditor but the holder of any bill to sue the initial debtor (Richards 2012, p. 23). 


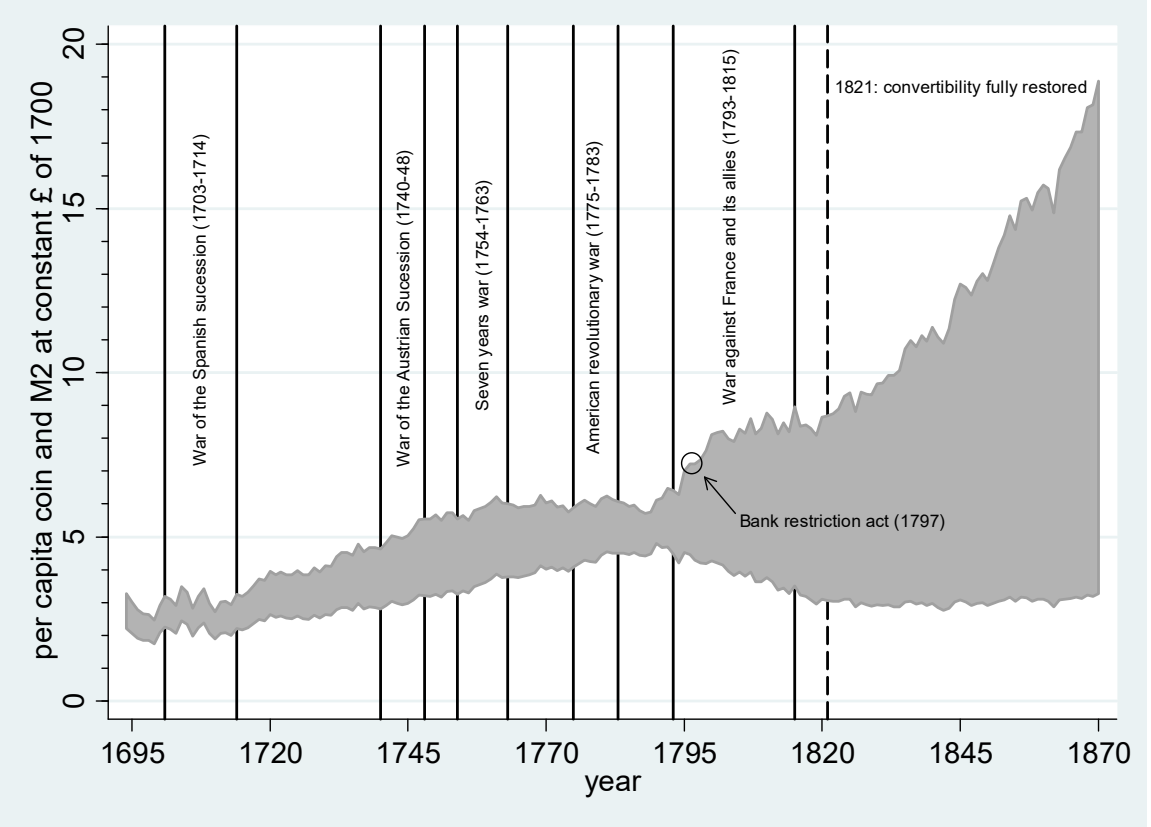

Figure 3. British per capita coin supply and M2 at constant prices of 1700 . The area in grey can be interpreted as the approximate size of inside money in circulation and held as store of value. Sources: this figure is derived using the indirect method described in Palma (2018), which in terms of data relies on Broadberry et al (2015), Capie (2004) and Mayhew (2013).

Further, the conditions of the second half of the seventeenth century in England may have been special, as they corresponded to what can essentially be described as financial sector catch-up with the best practices of the continent (Coffman, Leonard and Neal 2013). Hence, while credit did expand without an increase in coin in the second half of the second century, this process should be seen as a delayed response..

For the better part of the early modern period, credit and coin have been complements, not substitutes. Forms of exchange based on informal credit had been developing since the sixteenth century, but were inadequate as a substitute for coin: "the primary 
hindrance was that personal credit instruments did not circulate, at least not nearly enough to make a real difference. For commerce, agriculture and manufacturing to flourish, new sources of [outside] money had to be discovered" (Wennerlind 2011, p. $19) .{ }^{16}$

Hence, commodity-based coin and inside money (such as banknotes) were complements, not substitutes. ${ }^{17}$ It is clear that "in the international economy of the sixteenth and seventeenth centuries, the arrival and distribution of bullion ... was enough to set in motion a series of credit transactions" (Spooner 1972, p. 3). That is the view that modern economic theory also suggests (Holmström and Tirole 2011). Credit was, additionally, subject to usury restrictions that were binding, especially for those without exemptions or access to collateral (Temin and Voth 2008). The perceived need for means to expand currency in order to buttress commercial expansion is reflected in several contemporaneous intellectual and political debates which I discuss in the Appendix.

A final argument supports the idea that money and credit were complements. The decision to issue credit was often based on people's anticipation of whether the debtor would have the liquidity to honor the bill, and that in turn depended on the overall availability of money (Nightingale 2010). With regards to the medieval economy, peasants did use coin and were involved in market activity, to some extent, but they

${ }^{16}$ I added the word outside to make it clear that it is coin that is being referred here to as money. As Wennerlind (2011, p. 110) recognizes, William Paterson, the intellectual influence behind the creation of the Bank of England, felt that "Credit not founded on the Universal Species of Gold and Silver, is ... impracticable", and that a minimum reserve of 15-25 percent was necessary to make the system secure (Patterson 1694); Godfrey advocated a similar position (Wennerlind 2011, p. 112).

${ }^{17}$ Further, the expansion of paper credit was considered by contemporaries complementary to having a positive trade balance and hence access to foreign precious metals (Wennerlind 2011, p. 282 endnote $95)$. 
also faced persistent liquidity problems (Dyer 1997 p. 32, 44). Credit operations in the medieval countryside involved coined money at some stage. Credit was used in lieu of coin particularly during periods of coin shortage such as the final decades of the fourteenth century along with the fifteenth, and transaction costs involved in making payments using credit networks were higher than in using coin (Mayhew 2004, p. 80; Briggs 2005, Spufford 2002, p. 42-44).

In sum, there were only two ways by which people could issue credit, and both critically depended on reputation in the face of repeated relationships. First, richer merchants with established businesses could write bills of exchange, even internationally. Second, at the local village level, people could and did at times informally borrow small amounts from each other (Muldrew 1998). ${ }^{18}$ But this required personal and repeated relationships that necessarily limited the scope of credit - it created complications for the advancement of structural change and division of labor, which require the availability of an anonymous and liquid means of exchange for oneoff transactions in cities. The lack of an easily accessible liquid means of payment meant that in medieval economies payments often had to be made on a quarterly basis or through the "chalking up by local tradesmen of small debts for later settlement" (Mayhew 1995, p. 239), which surely increased credit risks and transaction costs, leading to a reduced number of equilibrium transactions.

\section{III}

Why did the early modern monetary injections matter? Research has shown that in England much of the occupational migration from agriculture to industry happened

${ }^{18}$ In Catholic countries the monasteries (or other religious institutions with charitable purposes) filled the function of monitoring borrowers. In Islamic countries, the Waqf had a similar role. 
during the early modern period (Broadberry et al 2013, p. 369; Leigh Shaw-Taylor and Wrigley 2014, p. 59). The industrial and service sectors already accounted for $40 \%$ of the labor force in 1381, and by 1759 agriculture's share of the labor force had shrunk to $37 \%$ and industry's grown to $34 \%$ (Broadberry et al 2013). Wallis et al. (2018) show that by the early eighteenth century, only around 45 percent of the male labor force was in agriculture. Structural transformation became particularly rapid in the decades surrounding the mid-seventeenth century (Wallis et al 2018), which also witnessed the beginnings of sustained economic growth (Broadberry et al 2015, Humphries and Weisdorf forthcoming).

From the 1630 s the gradual increase in availability of real coin supply per capita allowed for cash payments to become more frequent, structural change to begin, ${ }^{19}$ and income growth to occur. Higher monetization mattered directly, by making payments easier to make and receive, decreasing transaction costs and inducing specialization. The result was thicker markets and structural change. Higher liquidity also mattered indirectly, via spillover and general equilibrium effects. I now cover each of these effects separately, although they interacted with each other.

As far as transaction costs are concerned, the evidence we have is that making and receiving payments in cash was difficult even as late as the early seventeenth century. For example, an early seventeenth century yeoman for whom we have detailed accounting information wished to rely on wage labor rather than provide food and other in-kind payment to his servants. But he decided against it upon realizing that "he

\footnotetext{
${ }_{19}$ From Broadberry et al (2013), we do not know exactly when structural change started, only that it must have been between the 1520s and 1700. From Wallis et al (2018), however, we know that the 1630 s is a plausible decade.
} 
simply did not have access to enough ready money to pay regular cash wages" (Muldrew 2008, p. 401). ${ }^{20}$

A number of factors mattered for the growth of urbanization during the early modern period, such as the growth of international trade (Allen 2009 and Palma 2016). But it is undeniable that in kind payment is more difficult in cities, and that the lack of ready money was a reason why so much industry was traditionally located in the countryside (Muldrew 2008, p. 405, 410). Once liquidity became available, agglomeration economies could take place. This in turn lead to more urbanization, creating a positive feedback loop with higher specialization (division of labor), the spacial concentration of specialized human capital and further urbanization.

The provision of more liquidity also had important indirect effects. The inflow of American silver meant that new goods such as tea, porcelain and silk could be imported by the East India Company, and these are well known to have caused an industrious revolution. But the most important effects were dynamic. These can be separated into learning externalities, industrial expansion effects, and related demand effects. The new goods from Asia induced demand towards import substitutes, which spilled-over into industrial development. In England, it is hard to conceive of important porcelain centers such as Worcester or Derby having appeared if the early modern Euro-Asian trade had not happened. ${ }^{21}$ There was also additional demand of

\footnotetext{
${ }^{20}$ Note that this evidence is prior to the 1630 s, whereas I argue below that deep monetization started between 1630-1660.

${ }^{21}$ Elsewhere in the continent important centers also appeared at Delft, Chantilly, or Sèvres, yet in England the industrial effects were stronger. See Berg (2008).
} 
English products from first-order receivers of the silver and gold, Spain and Portugal. ${ }^{22}$

Tax collection was made easier by a more monetized and urbanized economy collection, raising the fiscal capacity of the state (Capie 2004, Desan 2014, p. 256). In turn, higher fiscal capacity meant that investment conditions were more attractive, and England could be a provider of carry trade services as a result of the force of the Royal Navy - itself a result of comparatively high fiscal capacity.

Monetary injections also helped in avoiding deflation. If the price level could adjust immediately to changes in money supply, then any change of unit of account or the overall quantity of money would not matter. As it was, whether due to social norms, menu costs, or other factors, price and especially wage rigidity was a reality (Palma 2016)..$^{23}$ In early modern England, despite the early modern price revolution which occurred prior to the eighteenth century, customary rents were normally fixed in nominal terms. Contracts often covered a number of generations, and there were substantial benefits for tenants who were able to defeat their lords' attempts to raise rents (Holt 2013). Indeed, not only was price adjustment persistently absent or incomplete for long periods of time, but it was also the case that it was asymmetric - in eighteenth-century France, for instance, following changes in the unit of account, upward price adjustments were much faster and less penalizing for the real economy than downward adjustments (Velde 2009).

\footnotetext{
22 "Through both legal and smuggled imports, effective Spanish demand, sustained by American silver, promoted the economic development of Holland, England, and other European countries" (Cipolla 1993).

23 Even in modern economies, labor markets often do not clear as nominal wages adjust slowly to changes in economic activity.
} 
Several recessionary mechanisms associated with deflation can be posited. Despite the relatively small size of financial intermediation, debt-deflation might have been a serious concern in the absence of the monetary injections. ${ }^{24}$ For a given country, as the internal price level falls the real exchange rate will appreciate and the economy will become less competitive. Furthermore, if deflation is avoided for a group of countries as a whole, this can be beneficial for all (Eichengreen and Sachs 1985). Expectations about continued falling prices may also lead people to delay consumption expenditures. As I have argued, in England, monetary injections mattered in part because the additional liquidity avoided persistent deflation. ${ }^{25}$ In the Middle Ages, supply of precious metals was quasi-fixed and hence deflation was a persistent phenomenon. According to the Broadberry et al (2015) price deflator, it took until the 1530 s for the price level to recover to the pre-Black Death level. This episode of persistent deflation from the fifteenth century onwards is associated with the late medieval bullion famine (Day 1956; Spufford 1989, p. 340, 343; Dyer 2002, pp. 266, 384.) Although some elements of the original story were subsequently criticized (Sussman 1998), the lack in the availability of precious metals was in fact at this time an important element in preventing growth (Miskimin 1964, Nightingale 1990, 1997, 2012; Desdan 2014; Goff 2012, p. 143).

Recent data suggests that England suffered from persistent secular deflation from the early-fourteenth century to the first decade of the 1530s (Broadberry et al 2015). ${ }^{26}$

${ }^{24}$ Debt-deflation is the fall in the prices of assets, goods or services that raises the real value of debt, which is written down nominally. In turn, this may lead to a negative cycle due to the fall in the value of collateral.

25 These are the reasons I emphasize in this paper; others may have been at play. In particular, I have here left out associated distributional implications.

26 In England, 1300-1525 was a period of arrested development, by comparison with 1000-1300 (Britnell, 1993, 2009). The latter period, when silver was still available in sufficient quantities, was characterized by increased commercialization, which included the establishment of active factor 
Figure 4 shows the evolution of the price level from the mid sixteenth century until 1790. ${ }^{27}$ The figure shows the observed price level and a counterfactual price level where the money supply is fixed at the 1550 level. The counterfactual evolution of the price level is calculated using the equation of exchange, MV=PY, and using the orthodox assumption that $\mathrm{Y}$ and $\mathrm{V}$ are independent of $\mathrm{M}$ in the long run. ${ }^{28}$

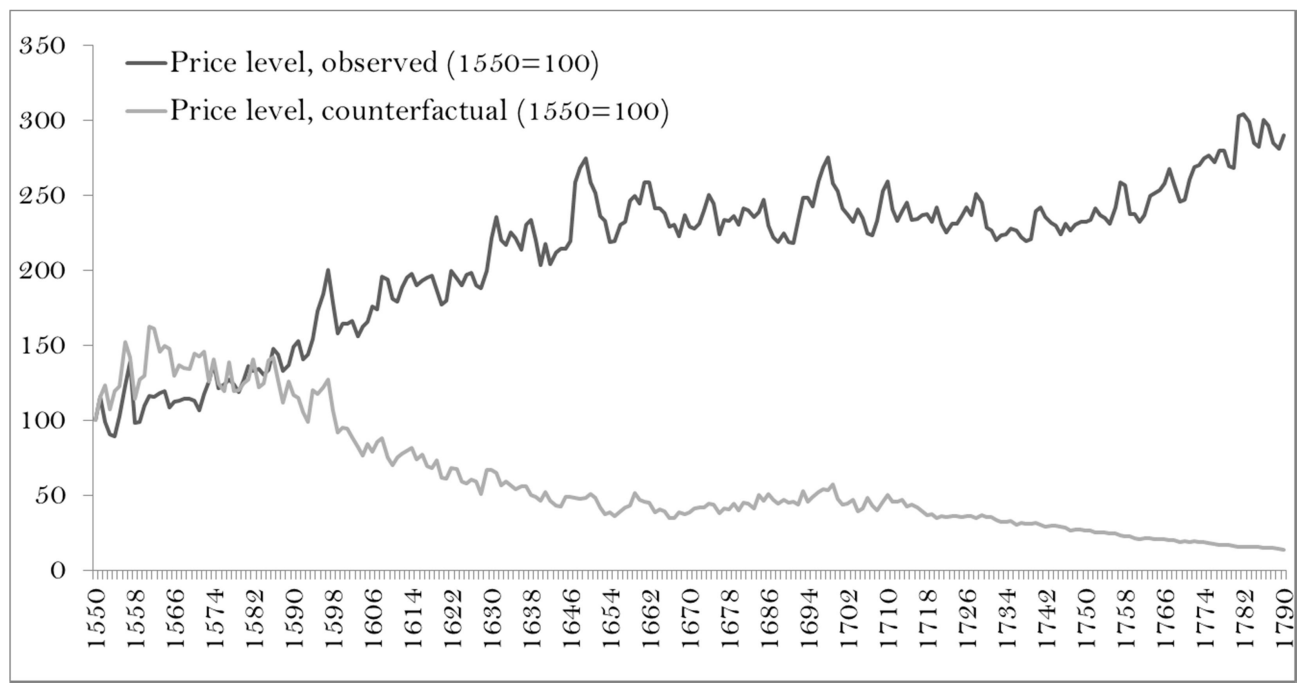

Figure 4. Observed and counterfactual price levels. Source: my calculations, using the 1550 money supply from Palma (2018), and for the price level, the GDP deflator of Broadberry et al (2015).

A short macroeconomic history of early modern England in relation to monetary history can hence be told as follows. The sixteenth century was a century of stagnation for England, both in terms of per capita real GDP and money supply. While silver was arriving from South America into Spain in significant quantities (and by extension, the

(Contd.)

markets for labor, land, and capital (Cambpell 2009). Spufford (2002, p.12 and 59) considers the growth in the money supply a necessary precondition for the commercial revolution which Europe witnessed in the thirteenth century.

${ }^{27}$ I stop in 1790 because the French Wars and the Bank Restriction act (1797) led to a monetary regime beyond the scope of this paper (O'Brien and Palma, forthcoming).

${ }^{28}$ Note that if $\mathrm{Y}$ (or its growth) was not independent of $\mathrm{M}$ (or its growth), that is, if monetary neutrality or superneutrality failed to hold, the main point that Figure 4 makes would still hold qualitatively, but there would have been both less growth and less deflation. 
territories of modern Belgium and Netherlands, as well as Italy), English nominal coin supply increased, but these increases were outweighed by increases in population and the price level. The increase in coin supply did lead to some inflation, which eventually terminated the previous status-quo of stagnating nominal wages. ${ }^{29}$ Inflation may have encouraged wage-labor share growth, and may have had other distributional consequences, ${ }^{30}$ but itdid not lead to observable per capita income growth. ${ }^{31}$

It took until the early seventeenth century for precious metals from America to start having a significant effect on England's money supply. This effect predates the very significant (for the standards of the time) growth which then occurred (Figure 5). From the Cottington Treaty of 1631 onwards, both private merchants and Asentistas in Spain sent silver bullion and coin to Flanders aboard English vessels. ${ }^{32}$ These would first stop in Dover where two-thirds of the silver would be transported to the Tower mint in London to be coined into English coinage. These agents would then "use the coined silver to buy bills of exchange from English merchants redeemable in Flanders" (Kepler 1976, p. 37). ${ }^{33}$

29 Dyer (2013, p. 22) writes that "The daily wage of building workers reached a plateau during the fifteenth century, which persisted until 1520, of $6 \mathrm{~d}$ per day for a skilled craftsman and $4 \mathrm{~d}$ for a labourer".

${ }^{30}$ Landes (2003 [1969], p.18) suggests that the long inflation of the sixteenth century, which "found many peasants holding long-term leases whose burden diminished" was strongly associated with reducing seigneurial authority and enhancing the personal and economic status of the peasantry. See also Whittle (2013, p. 12).

${ }^{31}$ This may have been for a number of reasons: decreasing real income of landowners; increased supply of labor having a contrary effect on the equilibrium real wage; and/or the increase in the share of pasture to the expense of arable land (as suggested by Thomas More's "sheep eating men" Utopia methaphor) decreasing agricultural labor demand, even if that was itself partly a response to initially "high" real wages. It is also the case that as long as large reserves of un-monetized workers still existed, a continued increase in the wage-labor force could proceed without an increase in either real wages or per capita GDP, which by definition only measure market compensation.

32 For the Cottington treaty, see Challis (1992, p. 318-320). Whether this agreement is due to Cottington himself or not is a matter of debate (see Taylor 1972 for the negative view), but that is immaterial to my argument.

${ }^{33}$ By 1632, "Strict surveillance was to be maintained to assure that a full two-thirds of arrivals went to the Mint” (Taylor 1972, p. 246). By 1638, "neither the provision of Flanders nor Spain's heavy dependence on imports could be supplied without recourse to English shipping" (Taylor 1972, p. 246). The rule was changed to only one-third minimum in mid-1630s ... [by which time] "the 
After 1639, a decisive defeat of the Dutch republic against the Spanish fleet meant that "Spain became even more dependent upon English carriers than she had been previously" (Kepler 1976, p. 65). After this date, the Spanish placed "vital importance ... on cultivating good relations with England (Kepler 1976, p. 66). But conversely, the volume of imported Spanish silver "explains why parliament, which was almost totally dependent upon the City for liquid funds ... was anxious to give all possible guarantees of State protection to the Spanish silver factors and their principals" (Kepler 1976, p. 85). ${ }^{34}$ The Dover entrepôt and the Cottington treaty succeeded during 16 years, 1631-1647. From this date onward, the Dutch took over much of this carrying trade (Kepler 1976, p. 90).

Figure 5 contrasts per capita coin supply and real income, focusing on the period after the Great Debasement of 1542-1552. As we can see, in the second half of the sixteenth century, real per capita coin supply was essentially trendless. It rose then sharply in the period 1620-40, slightly anticipating the persistent growth in per capita output. ${ }^{35}$ Coin supply then slowly decreased (in per capita terms), always staying well above the pre-1620s level. ${ }^{36}$ These changes over time illustrate well the limitation of the

(Contd.)

English as masters of the Channel were also masters of Spanish trade and ... Brussels protested from a position of dependence" (Taylor 1972, pp. 247-8).

${ }^{34}$ It is likely that the reason why England never created a West India Company was the fear that "English attacks upon homebound Spanish silver fleets might have greatly reduced or ended Silver exports to Dover and London" (Kepler, p. 86). Access to bullion imports was seen as a first strategic priority by the Commons. A dearth of new coin would have been seen as provoking a liquidity crisis in the City money market (Kepler 1976, p. 87).

35 Notice, however, that the 1600-1643 growth in money supply is conditional on the relatively high figure of $£ 10$ for 1643 , which is based on a relatively uncertain guesstimate based on civil war coin hoards (Mayhew 1995). If the 1643 figure was lower (see Palma 2018 for details), the rise in per capita money supply would be more contemporaneous to that of per capita GDP.

36 The period of extraordinarily high mint output of the 1630 s and early 1640 s "stretched the capacity of the Tower Mint" Besly (2003 p. 41), and "The commonwealth (1649-60) is marked by coinage of a somewhat plain, utilitarian nature Besly (2003 p. 123). Note also that the 1630 s explosion was not caused by technicalchange: "traditional methods were still in use as late as $1639-40$ and there is no 
monetary approach to the balance of payments (McCloskey and Zecher 1974), because they show that geopolitical changes often mattered more for explaining net flows of silver than variation in income or productivity (for an example, see Kepler 1976, p. 72).

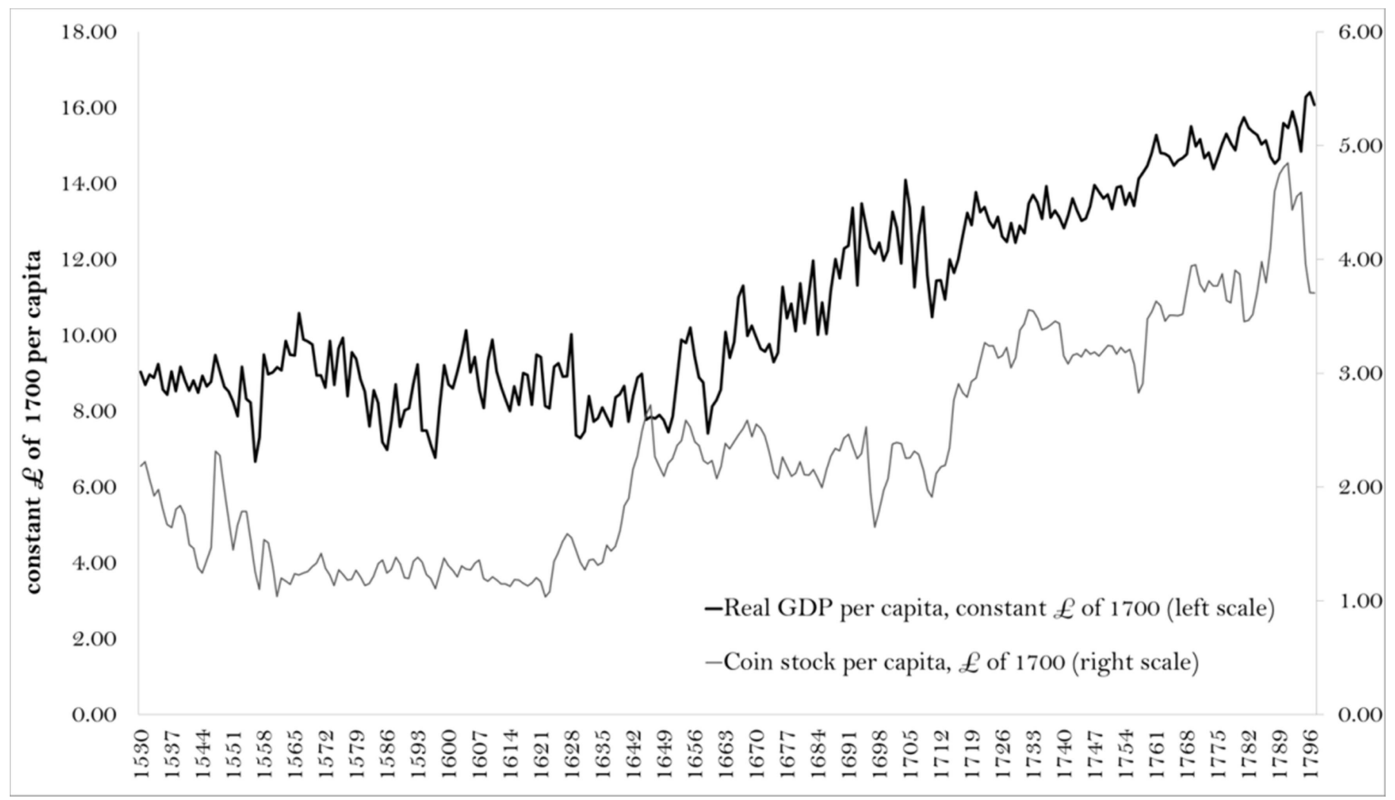

Figure 5. Real income and coin supply per capita. Sources: Broadberry et al (2015),

Palma (2018).

Stagnation in coin supply during the second half of the seventeenth century lead to coin of increasingly bad quality until the Great Recoinage of 1696, but this was largely compensated by circulation of inside money (Figure 6). ${ }^{37}$ Finally, in the eighteenth century, there was an increased availability of gold and a rise in per capita coin supply

(Contd.)

discernible change in technique for the rest of the reign or in the mainstream issues of the Commonwealth. The atrocious appearance of much Tower silver of the period can be explained as the result of the pressure of coining up to $£ 1$ million of Spanish silver a year by manual methods" Besly (2003, p. 124)

${ }^{37}$ A caveat to the intrepretation of the temporal correlation in Figure 6 is that the "M2" measure which I use there is in part derived by the income data, so there is some endogeneity by construction. Nevertheless, it is well known that various forms of credit developed over the second half of the seventeenth century (Wennerlind 2011), so the expansion of inside money there is a well-established historical fact. 
in association with the discovery of Brazilian gold and the Methuen Treaty, ${ }^{38}$ as well as with the Spanish Bourbon shift of the American empire towards the Mexican mines.

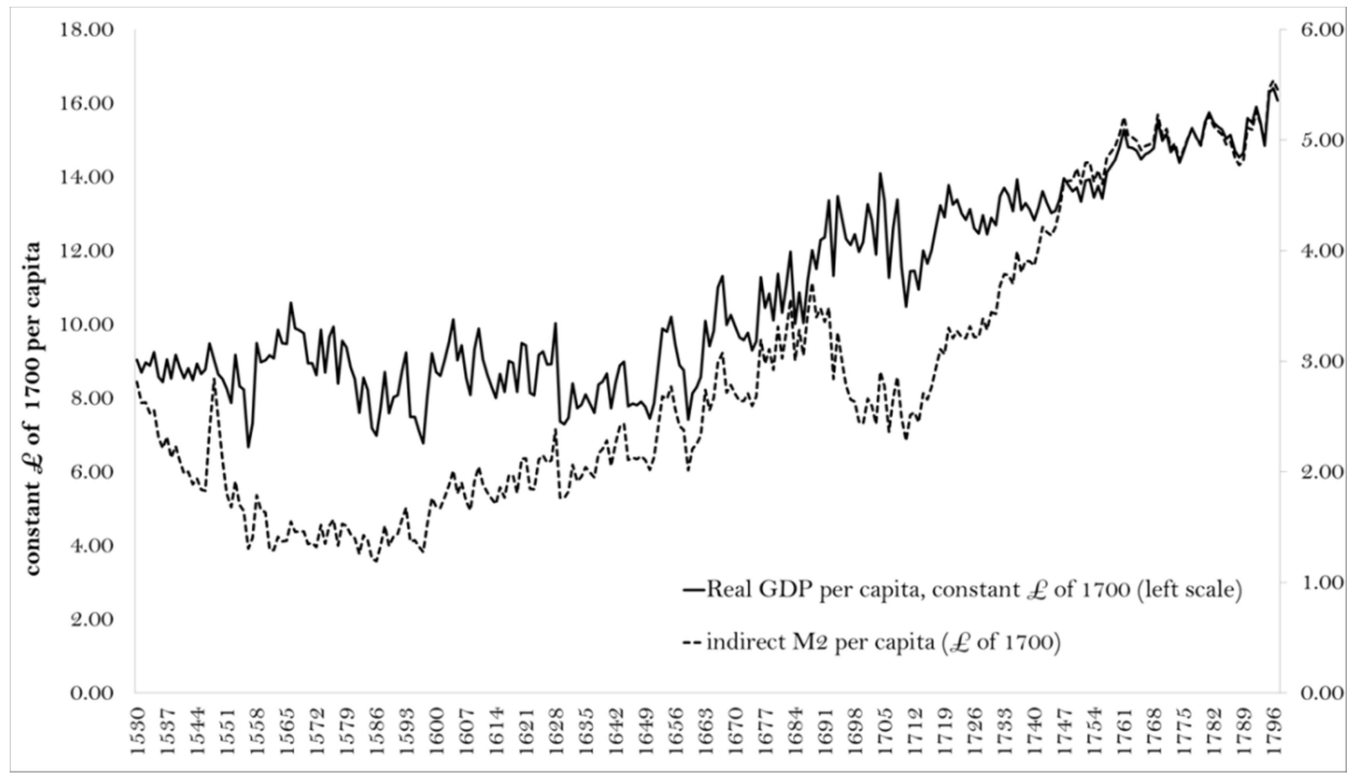

Figure 6. Real income and coin supply per capita. Sources: Palma (2018), and for the deflator, Broadberry et al (2015).

Several scholars claim that the early modern period was characterized by a dramatic lack of liquidity, and in particular a lack of small denominations (e.g. Muldrew 2008). ${ }^{39}$ But these studies present no systematic quantitative evidence that allows for either a

38 The 1703 Methuen treaty signed with Portugal was a military and commercial treaty which granted preferential custom treatment for Portuguese wines (diversifying away from French wines), in exchange for English manufactures. The differential value was paid in gold, and the timing of this treaty was determined by Portugal's finding of large quantities of gold in Brazil from the $1690 \mathrm{~s}$ onwards. As a consequence, two-thirds of Brazilian gold ended up in England: "Almost all our gold, it is said, comes from Portugal" [Smith 2003 (1776)]. The resulting monetary injection to the English economy was significant: about $\$ 40$ million for the $1700-1770$ period alone. Accordingly, Conduitt, the sucessor to Newton as master of the mint, claimed in 1730 that "nine parts of ten, or more, of all payments in England are now made in gold" (Challis 1992, p. 431).

${ }^{39}$ Seglin (2008) argues along similar lines, placing special emphasis on the eighteenth century. 
temporal or cross-sectional perspective. How can we in fact know which denominations circulated at different times?

Studying hoards is not ideal for this purpose, because people hoard at particular times, usually times of unrest - which explains why so many hoards exist for the civil war period (Besly 2003, p. 123). Accordingly, it is not surprising that large denominations dominate hoards even for periods when petty coins may have been much more important than the hoards suggest. A better option is the study of individual (stray) finds. These are coins that appear isolated because they were lost. They may appear in urban or rural contexts, often in the middle of rural fields likely due to having been lost in the floor of a home, swept away during cleaning and then released in the fields together with other domestic refuse which served as fertilizer (Dyer 1997, p. 36).

These individual coins are currently being found by metal detectors at a growing rate of several per year. In order to study denominations systematically, I rely on a UK government program called the Portable Antiquities Scheme which records findings of archeological interest by members of the public, often metal detectorists. ${ }^{40}$ Over 16,000 post-medieval coins have been recorded on the database; for this study I only consider single coin finds. ${ }^{41}$

Coin periods are identified by reigns. For each reign, I have counted the number of coins of each denomination as well as their total value. Tables A1 to A4 in the

\footnotetext{
40 The Portable Antiquities Scheme is available at https://finds.org.uk/

${ }^{41}$ Metal detectorists do not report early modern coins as much as medieval coins. They do not need as much expert help for later coins because they can read more easily what they need. Despite these caveats, the finds are the best indication we have of the denominations struck. Furthermore, to the extent that for later periods higher denominations are more likely to be reported - because the coins themselves appear more valuable - the resulting sample is biased against my argument. The same direction of bias happens because: "The Portable Antiquities Scheme regularly records all coins issued up to the end of the Commonwealth in 1660 , although we have to be more selective thereafter owing to the numbers of coins found", as reported in https://finds.org.uk/postmedievalcoins.
} 
Appendix show the full details, and Figure 7 summarizes the results. As the figure shows, denominations of 1 penny or less become common - more than $50 \%$ of finds only from the period of Charles I onward. ${ }^{42}$

Lucassen (2014, p. 74) defines deep monetization as the intersection of two conditions which are jointly sufficient for a society to be considered as such. First, denominations must exist which are equal to 1 hour or less of waged work. Second, these must exist in sufficiently large quantities, defined as a per capita quantity equal to five or more hours of waged work. If these conditions hold, a society can be considered to have a substantial stock of small change. He identified deep monetization as being present in the Netherlands in parts of the early modern period, as well as after 1840. Using this concept, I show here that the English economy was deeply monetized since at least 1630-1660.

Figure 8 considers the first of Lucassen's conditions. We can safely choose the penny as the smallest candidate denomination because the only other denomination which appears in significant quantities, the farthing, or a quarter of a penny would certainly not fulfill the second necessary condition - see Tables A1 to A4 in the Appendix. As Figure 8 shows, the period after 1630/1660 fulfills the first deep monetization condition. ${ }^{43}$

${ }_{42}^{4}$ Notice that the period of Henry VIII also looks comparatively well monetized but this was a period of enormous monetary disruption due to the Great Debasements.

43 Whether 1630 or 1660 is chosen as the best starting date depends on whether one selects 8 or 10 hours worked per day as a baseline; and of course, it is also the case that skilled workers would have hit this condition earlier than the unskilled (earnings in the graph are Clark's 2018 average). 
In turn, Figure 9 considers the second deep monetization condition. For which periods does small cash exist in sufficiently large quantities? Lucassen defines sufficiently large as a per capita quantity equal to five or more hours of waged work. Hence, I use the percentages in value equal or smaller than a penny from Tables A1-A4 in the Appendix, and I multiply this by the coin supply from Palma (2018). ${ }^{44}$ This gives me a measure of small cash available per capita, which I then divide by the average hourly nominal wages from Clark (2018). ${ }^{45}$ The result is shown in Figure 9; notice that I can only show this for the periods for which I have the denomination shares breakdown, hence 1509-1820.

${ }^{44}$ I include the royalist recoinage adjustment which I explain in the appendix.

${ }^{45}$ Hourly earnings are obtained directly from the nominal day earnings of Clark (2018). 


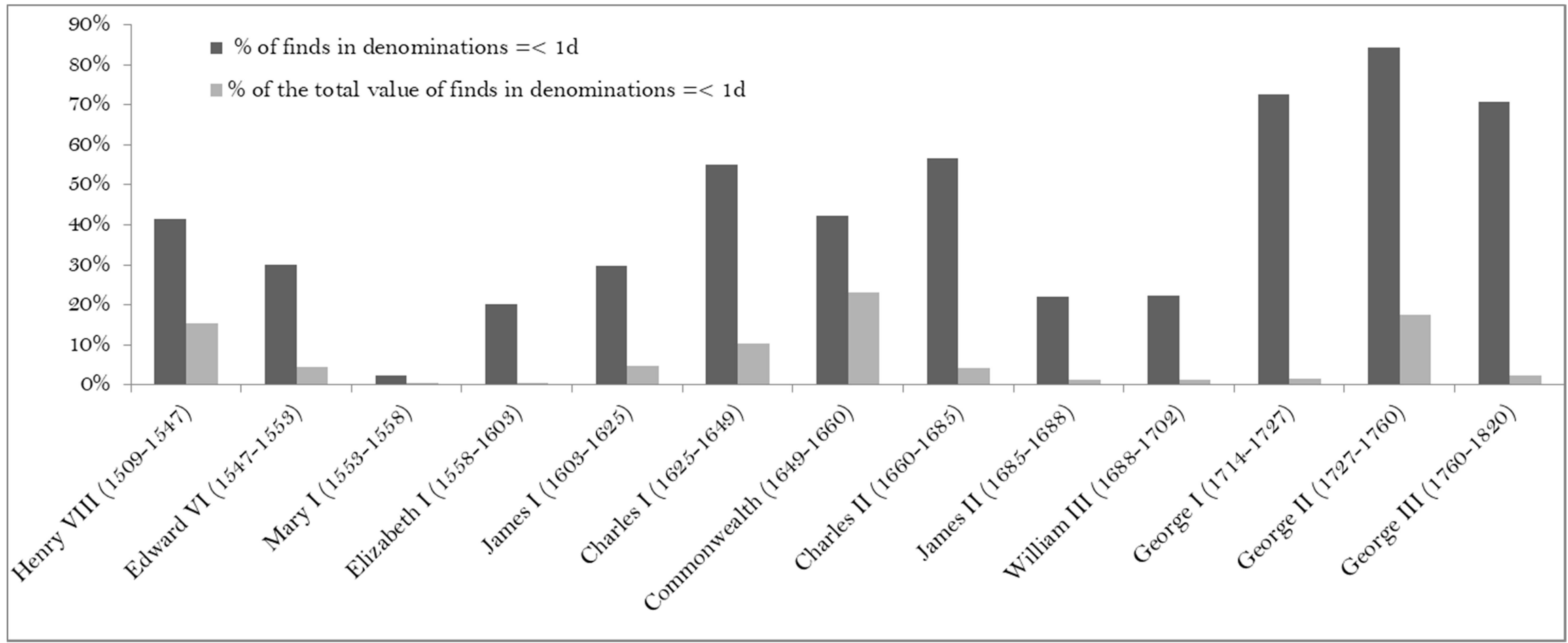

Figure 7. Distribution of denominations for different periods. Source: my calculations, using the raw data from the Portable Antiquities Scheme 


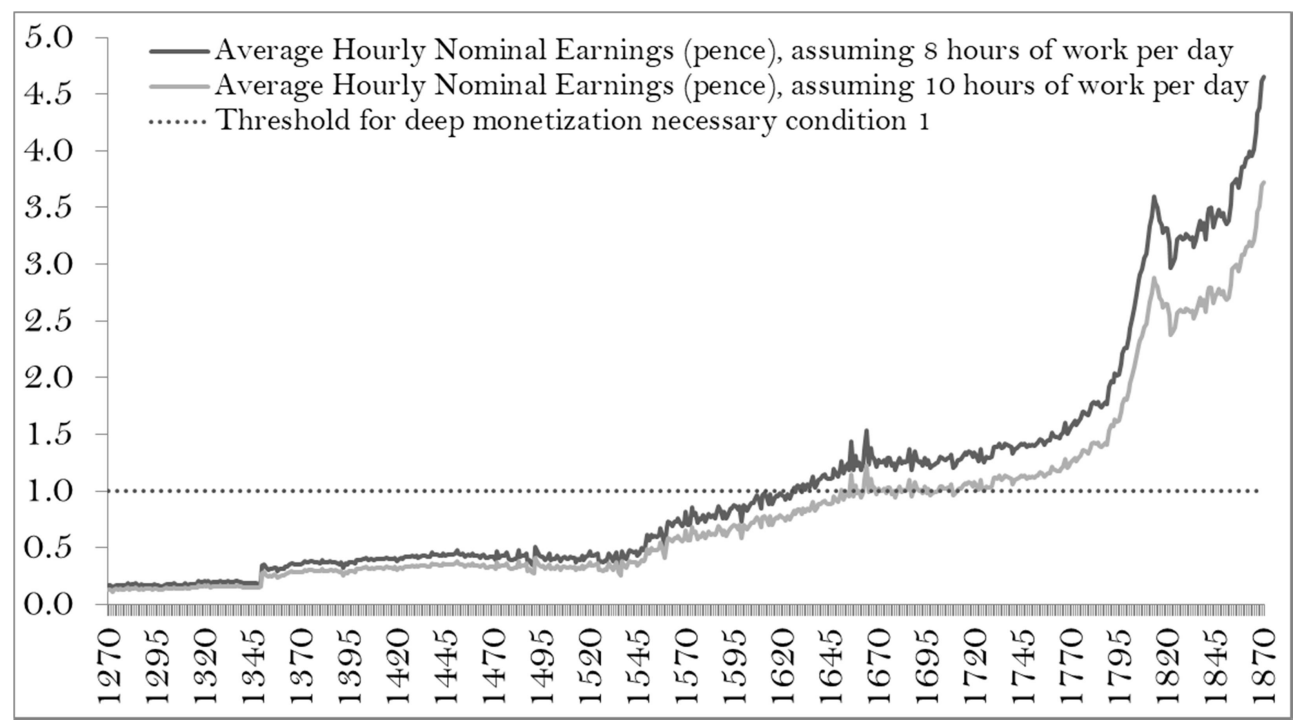

Figure 8. Deep monetization necessary condition 1: existence of small denominations.

Sources: Wages from Clark (2018), and for the threshold, see text.

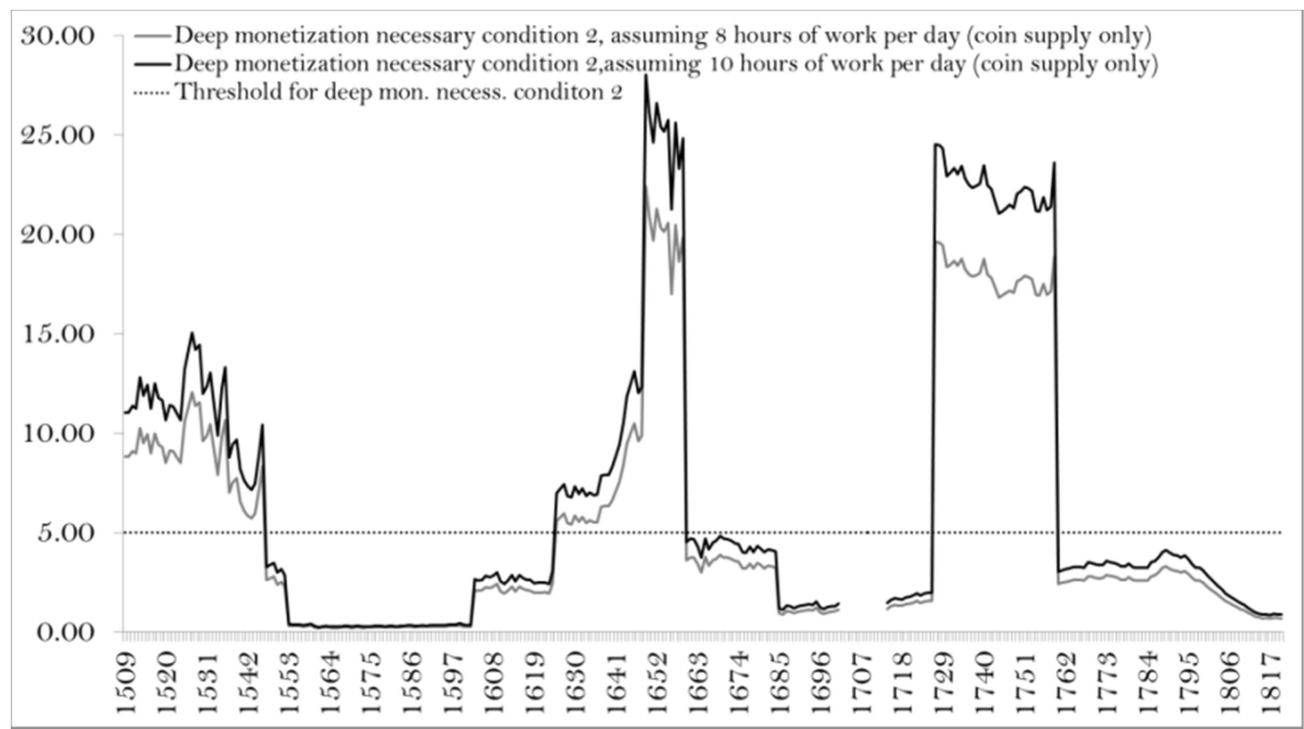

Figure 9. Deep monetization necessary condition 2: availability of sufficient cash.

Sources: see text.

If we intersect the necessary conditions of both figures, then we conclude that only the period 1630-1660, and again from the late 1720 s to about 1760 were deeply monetized 
in England. ${ }^{46}$ However, we should not be too quick to conclude that the second halves of the $17^{\text {th }}$ and $18^{\text {th }}$ centuries were not well monetized. First, notice that a large subset of these periods, 1660-1685 and 1760-1795 were below, but close, to the threshold. But more importantly, the figure only refers to coin supply availability. Since outside money such as inland bills of exchange and other forms of credit ${ }^{47}$ were also used, actual money supply was surely higher. ${ }^{48}$ Palma and O’Brien (forthcoming), for instance, document how after 1797 the Bank of England issued large quantities of banknotes of denominations low enough to pay wages, but this is not represented in Figures 8 and 9. Overall, I find strong evidence against Muldrew's claim that "liquidity was no better in the eighteenth and early nineteenth century" than in earlier periods (Muldrew 2008, p. 393).

\section{V}

Noting that in the Netherlands payment in kind was of secondary importance to cash during the early modern period, De Vries and Van der Woude (1997, pp. 81-89, 714) write that " $[\mathrm{m}]$ onetization is clearly a critical factor in the spread of the calculating, rational conduct that we associate with a modern society." There is little I can disagree with this statement, though the evidence for England does not support their later

${ }^{46}$ Notice that Lucassen (2014) finds that in the Netherlands only some periods over 1500-1800 were deeply monetized according to his own definition.

${ }^{47}$ Notice that some historical works take a very narrow view of what money is, and hence define credit as something separate from money, instead only considering coin as money. This is at odds with modern economics. Both coin and credit are money; the relevant distinction is that of outside vs. inside money (Holmström and Tirole 2011).

${ }_{48}$ Why not use M2 from Palma (2018) then? There are three reasons. First, such a measure as built in that paper is by construction endogenous to income. Second, the denomination structure from Tables A 1-A4 would no longer apply, so I would be unable to determine which part was composed of small denominations. Third, and relatedly, most inside money (e.g. inland bills) were of higher denominations. 
claim that "not until the nineteenth century did Europe raise up an equal in this respect”.

American precious metals permitted a dramatic increase in English monetization, which in turn generated Smithian growth, supported state-building and facilitated the transition into modern economic growth. From a comparative perspective, one important question is why this did not happen elsewhere, namely in the first-order receiving countries - Spain for the entire early modern period, and Portugal after about 1700 . One possibility is that these two countries suffered from the "Dutch disease" and institutional resource curses (Hamilton 1936, Drelichman 2005a, 2005b). But the Iberian path towards backwardness ${ }^{49}$ should not distract us from the possibility that those monetary injections led to positive - not only persistent, but permanent - longrun effects for England and the Netherlands. ${ }^{50}$ This has not been emphasized in the recent literature, but it did not go unnoticed by some contemporaries:

[S]ince the discovery of the mines in America, industry has increased in all the nations of Europe, except in the possessors of those mines; and this may justly be ascribed, amongst other reasons, to the increase of gold and silver ... $[\mathrm{T}]$ he prices of all things have only risen three, or at most, four times, since the discovery of the West Indies ... But will anyone assert, that there is not much more than four times the coin in Europe, that was in the fifteenth century, and the centuries preceding it? ... And no other satisfactory reason can be given, why all prices have not risen to a much more exorbitant height, except that which is derived from a change of

\footnotetext{
${ }^{49}$ Documented by Álvarez-Nogal and Prados de la Escosura (2013) and by Palma and Reis (forthcoming).

${ }^{50}$ For instance, during most of the seventeenth century, millions of pesos per year flowed from Spain to the Netherlands, where among other matters they funded the operations of the Bank of Amsterdam.
} 
customs and manners. Besides that more commodities are produced by additional industry, the same commodities come more to market, after men depart from their ancient simplicity of manners. (Hume 1987/1742, p. 33)

\section{References}

Allen, R. (2001). The Great Divergence in European Wages and Prices from the Middle Ages to the First World War. Explorations in Economic History 38, pp 411-447.

Allen, Martin Allen and D'Maris Coffman (2014). Money, Prices and Wages: Essays in Honour of Professor Nicholas Mayhew. Palgrave Macmillan

Álvarez-Nogal, Carlos and Leandro Prados de la Escosura (2013). The rise and fall of Spain (1270-1850). The Economic History Review 66 (1): 1-37

Ashton, T. H. (1997/1948). The Industrial Revolution, 1760-1830. Oxford University Press.

Attman, A. (1986). American bullion in the European World Trade: 1600-1800. Goteborg.

Barret, W. (1990). World bullion flows, 1450-1800, in: The Rise of Merchant Empires. Cambridge University Press. 
Besly, E. (2003). The coinage of the Stuarts. British Numismatic Journal, 73.

Briggs, C. (2015). Money and Rural Credit in the Later Middle Ages Revisited. In Money, Prices and Wages (pp. 129-142). Palgrave Macmillan, London.

Broadberry, Stephen, Bruce M. S. Campbell, and Bas van Leeuwen (2013). When Did Britain Industrialise? The Sectoral Distribution of the Labour Force and Labour Productivity in Britain, 1381-1851. Explorations in Economic History 50, no. 1 (2013): 16-27.

Braudel, F. P., and F. Spooner (1967). Prices in Europe from 1450 to 1750, in The Cambridge Economic History of Europe from the Decline of the Roman Empire, ed. by E. E. Rich, C. H. Wilson, E. E. Rich, and C. H. Wilson, pp. 374--486. Cambridge University Press, Cambridge.

Brewer, J. (1989). The Sinews of Power. Harvard University Press

Briggs C. (2015) Money and Rural Credit in the Later Middle Ages Revisited. In: Allen M., Coffman D. (eds) Money, Prices and Wages. Palgrave Studies in the History of Finance. Palgrave Macmillan, London

Britnell, R. (1993). Commerce and Capitalism in Late Medieval England: Problems of Description and Theory. Journal of Historical Sociology 6 (4)

Britnell, R. (2009). The Commercialisation of English Society 1000-1500. Cambridge University Press. Reprint of the 1993 edition. 
Broadberry, Stephen (2013). Accounting for the great divergence. Economic History Working Papers, 184/13. LSE

Broadberry, S., Campbell, B. M., and van Leeuwen, B. (2013). When did Britain industrialise? The sectoral distribution of the labour force and labour productivity in Britain, 1381-1851. Explorations in Economic History 50(1), 1627.

Broadberry, Stephen, Bruce Campbell, Alexander Klein, Mark Overton, and Bas van Leeuwen (2015). British Economic Growth, 1270-1870. Cambridge University Press

Capie, F. (2004). Money and economic development in England. In: Exceptionalim and industrialization, edited by Prados de la Escosura. Cambridge University Press

Challis (1992). A New History of the Royal Mint. Cambridge University Press

Cipolla, Carlo M. (1993). Before the Industrial Revolution: European Society and Economy 1000-1700. Routledge

Clark, Gregory (2018). Average Earnings and Retail Prices, UK, 1209-2017. Accessed September 2018 from: https://www.measuringworth.com/datasets/ukearncpi/ 
Clancy, K. (1999). The recoinage and exchange of 1816-17. PhD thesis, University of Leeds

Clapham, J. (1944) The Bank of Engand, a history. 2 vols, Cambridge

Coffman, D., Leonard, L. and L. Neal (eds.) (2013). Questioning Credible Commitment. Cambridge University Press

Craig, J. (2011 [1953]). The Mint: A History of the London Mint from A.D. 287 to 1948. Cambridge University Press

de Vries, J. (1994). The industrial revolution and the industrious revolution. The Journal of Economic History, 54(02), 249-270.

de Vries, J. (2008). The industrious revolution: consumer behavior and the household economy, 1650 to the present. Cambridge University Press.

de Vries, J., and Van der Woude, A. (1997). The first modern economy: Success, failure, and perseverance of the Dutch economy, 1500-1815. Cambridge University Press.

Desan, C. (2014). Making Money: Coin, Currency, and the Coming of Capitalism. Oxford University Press

Dickson, Peter (1993/1967). The Financial Revolution in England: A Study in the Development of Public Credit, 1688-1756. Gregg Revivals 
Drelichman, Mauricio (2005a). The curse of Moctezuma: American silver and the Dutch disease. Explorations in Economic History 42 (3), 349-380

Drelichman, Mauricio (2005b). All that glitters: Precious metals, rent seeking and the decline of Spain. European Review of Economic History 9 (3), 313-336

Dyer, C. (1997). Peasants and Coins: the uses of money in the middle ages. British Numismatic Journal, 67, 30-47.

Dyer, C. (2002). Making a living in the Middle Ages: The people of Britain, 850-1520. Yale University Press

Dyer, C. (2013). The Agrarian Problem, 1440-1520. In: Landlords and Tenants in Britain, 1440-1660: Tawney's Agrarian Problem Revisited. The Boydell Press

Eichengreen, B. and J. Sachs (1985). Exchange Rates and Economic Recovery in the 1930s. The Journal of Economic History 45, issue 04, pp 925-946

Feavearyear A.E. (1944). The Pound Sterling. A History of English Money. Oxford Goff, Jaques Le (2012). Money and the Middle Ages. Polity Press

Gould, J. (1964). The Price Revolution Reconsidered. Economic History Review 17, pp. $249-66$ 
Hamilton, E. J. (1970). American Treasure and the Price Revolution in Spain, 15011650. Octagon.

Holmström, B., and Tirole, J. (2011). Inside and outside liquidity. MIT press Holt, J. (2013). The Financial Rewards of Winning the Battle for Secure Customary Tenure. In: Landlords and Tenants in Britain, 1440-1660: Tawney's Agrarian Problem Revisited (ed. Jane Whittle). Boydell

Hume (1987/1742). Essays, Moral, Political, and Literary. Indianapolis, IN: Liberty Fund, Inc. Liberty Fund. Accessed May 2014 from http://www.econlib.org/library/LFBooks/Hume/hmMPL26.html

Humphries, Jane and Jacob Weisdorf (forthcoming). Unreal Wages? Real Income and Economic Growth in England, 1260-1850. Economic Journal

Kepler, J. S. (1976). The exchange of Christendom: The international entrepôt at Dover 1622-1651. Leicester University Press.

Landes, D. (2003/1969). The Unbound Prometheus: Technological Change and Industrial Development in Western Europe from 1750 to the Present. Cambridge University Press

Lucassen, J. (2014). Deep Monetisation: The Case of the Netherlands 12001940. Tijdschrift voor Sociale en Economische Geschiedenis, 11(3), 73.

McCloskey, D. N. and Zecher, J. R. (1976). How the Gold Standard Worked, 
1880-1913. In: The Monetary Approach to the Balance of Payments ,184-208.

Routlege

Mayhew, Nicholas J. (1995). Population, money supply, and the velocity of circulation in England 1300-1700. Economic History Review, 2, 238--257.

Mayhew, N. J. (2013). Prices in England, 1170-1750. Past छ Present, 219(1), 339.

Miskimin, H. A. (1964). Monetary movements and market structure: forces for contraction in fourteenth-century England. Journal of Economic History 24

Muldrew, C. (1998). Economy of Obligation: the Culture of Credit and Social Relations in Early Modern England. Palgrave

Muldrew, Craig (2008). Wages and the Problem of Monetary Scarcity in Early Modern England. In: Wages and Currency. Global Comparisons from Antiquity to the Twentieth Century Wages and Currency, ed. Jan Lucassen. International and Comparative Social History, vol.10.

Munro, J. (2011). The Coinages and Monetary Policies of Henry VIII (r. 15091547): Contrasts between Defensive and Aggressive Debasements. Working Paper no. 417 
Nightingale, Pamela (1990). Monetary Contraction and Mercantile Credit in Later Medieval England. Economic History Review 48

Nightingale, Pamela (1997). England and the European Depression of the midfifteenth century. Journal of European Economic History 26, pp. 631-56

Nightingale, Pamela (2010). Gold, Credit, and Mortality: Distinguishing Deflationary Pressures on the Late Medieval English Economy. The Economic History Review, Vol. 63, No. 4, pp. 1081-1104

O'Brien, P. (1988). The political economy of British taxation, 1660-1815. The Economic History Review 41 (1), 1-32

O'Brien, P. and Nuno Palma (forthcoming). Danger to the Old Lady of Threadneedle Street? The Bank Restriction Act and the regime shift to paper money, 1797-1821. European Review of Economic History

Palma, N. (2015). Sailing away from Malthus: intercontinental trade and European economic growth, 1500-1800 Cliometrica (2016) 10 (2), pp 129-149

Palma, N. (2016). The existence and persistence of liquidity effects: evidence from a large-scale historical natural experiment. GGDC Research Memorandum 158

Palma, N. (2018). Reconstruction of money supply over the long-run: the case of England, 1270-1870. Economic History Review 71 (2): 373-392 
Palma, N. and J. Reis (forthcoming). From convergence to divergence: Portuguese demography and economic growth, 1500-1850. Journal of Economic History

Palma, N. and A. C. Silva (2016). Spending a Windfall: American Precious Metals and Euro-Asian Trade, 1531-1810. GGDC working paper

Paterson, William (1694). A Brief Account Of the Intended Bank of England. London

Persson, K. G., and Sharp, P. (2015). An economic history of Europe. Cambridge University Press.

Porter, R. (1998). London: a social history. Harvard University Press. Chicago

Pressnell, L. S. (1956). Country banking in the industrial revolution. Oxford: Clarendon Press.

Redish, Angela (1990). The Evolution of the Gold Standard in England. The Journal of Economic History 50:(4)

Richards, R. D. (2012). The Early History of Banking in England. London: Routledge 
Sargent and Velde (2002). The Big Problem of Small Change. Princeton University Press

Schwarz, L. D. (1985). The Standard of Living in the Long Run: London, 17001860. The Economic History Review, 38, (1), pp. 24-41

Selgin, G. (2008). Good Money: Birmingham Button Makers, the Royal Mint, and the Beginnings of Modern Coinage, 1775-1821. Independent Publishers Group

Shaw-Taylor, Leigh and E. A. Wrigley (2014). Occupational structure and population change', forthcoming in Floud, R., Humphries, J., Johnson, P., (eds) The Cambridge Economic History of Modern Britain, 4th edition, Cambridge University Press

Smith, A. (2003). The Wealth of Nations. Bantam Dell.

Spufford, P. (1989). Money and its use in Medieval Europe. Cambridge University Press

Spufford, P. (2002). Power and Profit: The Merchant in Medieval Europe. Thames \& Hudson

Taylor, H. (1972). Trade, Neutrality, and the” English Road",-1630-1648. The Economic History Review, 25(2), 236-260 
Temin, P. and Hans-Joachim Voth (2008). Interest rate restrictions in a natural experiment: Loan allocation and the change in the usury laws in 1714. The Economic Journal 118, pp. 743-758)

Velde, F. R. (2009). Chronicle of a Deflation Unforetold. Journal of Political Economy 117(4), 591-634.

Wallis, P., Colson, J., and Chilosi, D. (2018). Puncturing the Malthus delusion: structural change in the British economy before the industrial revolution, 15001800. Journal of Economic History

Wennerlind, Carl (2011). Casualties of Credit: The English Financial Revolution. Harvard University Press

Whittle, J. (2013). Introduction. In: Landlords and Tenants in Britain, 1440-1660: Tawney's Agrarian Problem Revisited. The Boydell Press. 


\section{$\underline{\text { Appendix }}$}

\section{Improvement to the Palma (2018) coin supply data}

Royalist recoinage. With the return of the Stuarts to the throne in the person of Charles II, mint output temporally peaked due to the demonetization of the Commonwealth issues. This recoinage was announced in September 1661 and lasted until 1663; which leads to unusually high coin output during 1662-1663 (Challis 1992, pp. 338-9). I had not corrected for this recoinage in Palma (2018), but I do so here, using the figures Challis calls the lion's share: $£ 500,000$ (rounded up from $£ 489,157+£ 6,496$ ), which I divide equally among 1662-3. This correction leads to normal-looking nominal mint figures for 1662-3, considering that in 1662 there was also the minting of a large quantity of French coin received in payment for Dunkirk: $£ 327,726$ (Challis 1992, p. 339).

\section{Sources and methodological notes for tables A1 to A4}

The main denominations are shown out of the denominations for which at least 10 coins have been found for any of the periods. Accordingly, percentages shown in the tables do not sum to 100 . Foreign coinage generally excluded; some Scottish coins may be included, but when a denomination is known to have been exclusively Scottish (e.g. twenty pence under Charles I) it is excluded. Counterfeits are included, though rare. Guineas are assumed to be worth 20 shillings ( 1 pound) until George I and 21 shillings (252p) from then onwards. I do not show statistics for the reign of Queen Anne because only a few coins have been found correspondent to that short reign. The source is the Portable Antiques Scheme website, last accessed September 2018. 
Table A1.

Main denominations

issued 1509-1603

\begin{tabular}{|c|c|c|c|c|c|c|c|c|}
\hline & & Farthing & Penny & $\begin{array}{l}\text { Halfgroat or } \\
\text { two-pence }\end{array}$ & Threepence & $\begin{array}{c}\text { Groat or } \\
\text { fourpence }\end{array}$ & Sixpence & $\begin{array}{c}\text { Shilling } \\
\text { (including } \\
\text { Testoons) } \\
\end{array}$ \\
\hline Value in $\mathrm{d}$ & & 0.25 & 1 & 2 & 3 & 4 & 6 & 12 \\
\hline \multirow{4}{*}{$\begin{array}{c}\text { Henry VIII } \\
(1509-1547)\end{array}$} & $\begin{array}{c}\text { number of } \\
\text { finds }\end{array}$ & 16 & 575 & 562 & 0 & 652 & 0 & $\mathrm{O}$ \\
\hline & $\%$ of finds & $0.8 \%$ & $27.3 \%$ & $26.7 \%$ & $0.0 \%$ & $31.0 \%$ & $0.0 \%$ & $0.0 \%$ \\
\hline & $\begin{array}{l}\text { value of finds } \\
\text { (in } £ \text { ) }\end{array}$ & 4 & 575 & 1124 & o & 2608 & 0 & $\mathrm{O}$ \\
\hline & $\begin{array}{l}\text { value of finds } \\
\text { (in \% of the } \\
\text { total value) }\end{array}$ & $0.1 \%$ & $12.4 \%$ & $24.2 \%$ & $0.0 \%$ & $56.1 \%$ & $0.0 \%$ & $0.0 \%$ \\
\hline \multirow{4}{*}{$\begin{array}{l}\text { Edward VI } \\
(1547-1553)\end{array}$} & $\begin{array}{c}\text { number of } \\
\text { finds }\end{array}$ & 5 & 126 & 0 & 3 & 88 & 38 & 168 \\
\hline & $\%$ of finds & $1.1 \%$ & $28.8 \%$ & $0.0 \%$ & $0.7 \%$ & $20.1 \%$ & $8.7 \%$ & $38.4 \%$ \\
\hline & $\begin{array}{l}\text { value of finds } \\
\text { (in } £ \text { ) }\end{array}$ & 1.25 & 126 & o & 9 & 352 & 228 & 2016 \\
\hline & $\begin{array}{l}\text { value of finds } \\
\text { (in \% of the } \\
\text { total value) } \\
\end{array}$ & $0.0 \%$ & $4.5 \%$ & $0.0 \%$ & $0.3 \%$ & $12.5 \%$ & $8.1 \%$ & $71.6 \%$ \\
\hline \multirow{4}{*}{$\begin{array}{c}\text { Mary I } \\
(1553-1558)\end{array}$} & $\begin{array}{c}\text { number of } \\
\text { finds }\end{array}$ & $\mathrm{O}$ & 24 & 15 & o & 984 & 5 & 2 \\
\hline & $\%$ of finds & $0.0 \%$ & $2.3 \%$ & $1.5 \%$ & $0.0 \%$ & $95.5 \%$ & $0.5 \%$ & $0.2 \%$ \\
\hline & $\begin{array}{l}\text { value of finds } \\
\text { (in } £)\end{array}$ & $\mathrm{O}$ & 24 & 30 & $\mathrm{O}$ & 3936 & 30 & 24 \\
\hline & $\begin{array}{l}\text { value of finds } \\
\text { (in \% of the } \\
\text { total value) }\end{array}$ & $0.0 \%$ & $0.6 \%$ & $0.7 \%$ & $0.0 \%$ & $97.3 \%$ & $0.7 \%$ & $0.6 \%$ \\
\hline \multirow{4}{*}{$\begin{array}{l}\text { Elizabeth I } \\
(1558-1603)\end{array}$} & $\begin{array}{c}\text { number of } \\
\text { finds }\end{array}$ & 1 & 2585 & 3242 & 2747 & 614 & 4184 & 601 \\
\hline & $\%$ of finds & $0.0 \%$ & $17.7 \%$ & $22.1 \%$ & $18.7 \%$ & $4.2 \%$ & $26.6 \%$ & $4.1 \%$ \\
\hline & $\begin{array}{l}\text { value of finds } \\
\text { (in } £ \text { ) }\end{array}$ & 0.25 & 2585 & 6484 & 8226 & 2456 & 2514 & 7212 \\
\hline & $\begin{array}{l}\text { value of finds } \\
\text { (in \% of the } \\
\text { total value) } \\
\end{array}$ & $0.0 \%$ & $4.9 \%$ & $12.3 \%$ & $15.6 \%$ & $4.7 \%$ & 47.6 & $13.7 \%$ \\
\hline
\end{tabular}


Table A2.

Main denominations issued

1603-1660

\begin{tabular}{|c|c|c|c|c|c|c|}
\hline & & Farthing & Penny & $\begin{array}{l}\text { Halfgroat or two- } \\
\text { pence }\end{array}$ & Sixpence & $\begin{array}{l}\text { Shilling } \\
\text { (including } \\
\text { Testoons) }\end{array}$ \\
\hline Value in $\mathbf{d}$ & & 0.25 & 1 & 2 & 6 & 12 \\
\hline \multirow{4}{*}{$\begin{array}{c}\text { James I } \\
(1603-1625)\end{array}$} & number of finds & 389 & 463 & 946 & 729 & 445 \\
\hline & $\%$ of finds & $12.7 \%$ & $15.1 \%$ & $30.9 \%$ & $23.8 \%$ & $14.5 \%$ \\
\hline & $\begin{array}{l}\text { value of finds (in } \\
\qquad)^{\text {) }}\end{array}$ & 97.25 & 463 & 1892 & 4374 & 5340 \\
\hline & $\begin{array}{c}\text { value of finds (in \% } \\
\text { of the total value) }\end{array}$ & $0.8 \%$ & $3.7 \%$ & $15.3 \%$ & $35.3 \%$ & $43.1 \%$ \\
\hline \multirow{4}{*}{$\begin{array}{c}\text { Charles I } \\
(1625-1649)\end{array}$} & number of finds & 2913 & 1159 & 1603 & 502 & 778 \\
\hline & $\%$ of finds & $38.5 \%$ & $15.3 \%$ & $21.2 \%$ & $6.6 \%$ & $10.3 \%$ \\
\hline & $\begin{array}{c}\text { value of finds (in } \\
\mathscr{L} \text { ) }\end{array}$ & 728.25 & 1159 & 3206 & 3012 & 9336 \\
\hline & $\begin{array}{c}\text { value of finds (in \% } \\
\text { of the total value) }\end{array}$ & $3.9 \%$ & $6.2 \%$ & $17.1 \%$ & $16.1 \%$ & $49.9 \%$ \\
\hline \multirow{4}{*}{$\begin{array}{l}\text { Commonwealth } \\
(1649-1660)\end{array}$} & number of finds & 10 & 363 & 500 & $\mathrm{O}$ & 17 \\
\hline & $\%$ of finds & $1.1 \%$ & $38.9 \%$ & $53.6 \%$ & $0.0 \%$ & $1.8 \%$ \\
\hline & $\begin{array}{c}\text { value of finds (in } \\
\mathscr{E} \text { ) }\end{array}$ & 2.5 & 363 & 1000 & $\mathrm{O}$ & 204 \\
\hline & $\begin{array}{l}\text { value of finds (in \% } \\
\text { of the total value) }\end{array}$ & $0.2 \%$ & $22.3 \%$ & $61.4 \%$ & $0.0 \%$ & $12.5 \%$ \\
\hline
\end{tabular}


Table A3.

Main denominations

issued 1660-1702

\begin{tabular}{|c|c|c|c|c|c|c|c|c|c|}
\hline & & Farthing & Halfpenny & Penny & $\begin{array}{l}\text { Halfgroat or } \\
\text { two-pence }\end{array}$ & Sixpence & Half guinea & $\begin{array}{c}\text { Shilling } \\
\text { (including } \\
\text { Testoons) } \\
\end{array}$ & Guinea \\
\hline Value in $\mathbf{d}$ & & 0.25 & 0.5 & 1 & 2 & 6 & 10 & 12 & 20 \\
\hline \multirow{4}{*}{$\begin{array}{c}\text { Charles II } \\
(1660-1685)\end{array}$} & $\begin{array}{c}\text { number of } \\
\text { finds }\end{array}$ & 465 & 45 & 120 & 160 & 37 & 6 & 54 & 16 \\
\hline & $\%$ of finds & $41.8 \%$ & $4.0 \%$ & $10.8 \%$ & $14.4 \%$ & $3.3 \%$ & $0.5 \%$ & $4.9 \%$ & $1.4 \%$ \\
\hline & $\begin{array}{c}\text { value of } \\
\text { finds (in } \mathscr{E} \text { ) }\end{array}$ & 116.25 & 22.5 & 120 & 320 & 222 & O & 648 & 3840 \\
\hline & $\begin{array}{c}\text { value of } \\
\text { finds (in \% } \\
\text { of the total } \\
\text { value) }\end{array}$ & $1.9 \%$ & $0.4 \%$ & $2.0 \%$ & $5.4 \%$ & $3.7 \%$ & $0.0 \%$ & $10.8 \%$ & $64.2 \%$ \\
\hline \multirow{4}{*}{$\begin{array}{c}\text { James II } \\
(1685-1688)\end{array}$} & $\begin{array}{c}\text { number of } \\
\text { finds }\end{array}$ & 11 & 29 & 14 & 19 & 13 & 1 & 93 & 4 \\
\hline & $\%$ of finds & $4.5 \%$ & $11.8 \%$ & $5.7 \%$ & $7.7 \%$ & $5.3 \%$ & $0.4 \%$ & $37.8 \%$ & $1.6 \%$ \\
\hline & $\begin{array}{c}\text { value of } \\
\text { finds (in } \mathscr{E} \text { ) }\end{array}$ & 2.75 & 14.5 & 14 & 38 & 78 & 0 & 1116 & 960 \\
\hline & $\begin{array}{c}\text { value of } \\
\text { finds (in \% } \\
\text { of the total } \\
\text { value) } \\
\end{array}$ & $0.1 \%$ & $0.6 \%$ & $0.6 \%$ & $1.6 \%$ & $3.2 \%$ & $0.0 \%$ & $46.2 \%$ & $39.8 \%$ \\
\hline \multirow{4}{*}{$\begin{array}{l}\text { William III } \\
(1688-1702)\end{array}$} & $\begin{array}{c}\text { number of } \\
\text { finds }\end{array}$ & 195 & 249 & 14 & 2 & 1080 & 13 & 439 & 4 \\
\hline & $\%$ of finds & $9.4 \%$ & $12.1 \%$ & $0.7 \%$ & $0.1 \%$ & $52.3 \%$ & $0.6 \%$ & $21.3 \%$ & $0.2 \%$ \\
\hline & $\begin{array}{c}\text { value of } \\
\text { finds (in } \mathscr{L} \text { ) }\end{array}$ & 48.75 & 124.5 & 14 & 4 & 6480 & 1560 & 5268 & 960 \\
\hline & $\begin{array}{l}\text { value of } \\
\text { finds (in \% } \\
\text { of the total } \\
\text { value) }\end{array}$ & $0.3 \%$ & $0.8 \%$ & $0.1 \%$ & $0.0 \%$ & $44.2 \%$ & $10.6 \%$ & $36.0 \%$ & $6.6 \%$ \\
\hline
\end{tabular}


Table A4.

Main denominations

issued 1714-1820

\begin{tabular}{|c|c|c|c|c|c|c|c|c|c|}
\hline & & Farthing & Halfpenny & Penny & $\begin{array}{l}\text { Halfgroat or } \\
\text { two-pence }\end{array}$ & Sixpence & Half guinea & $\begin{array}{c}\text { Shilling } \\
\text { (including } \\
\text { Testoons) } \\
\end{array}$ & Guinea \\
\hline Value in $\mathrm{d}$ & & 0.25 & 0.5 & 1 & 2 & 6 & 10.5 & 12 & 21 \\
\hline \multirow{4}{*}{$\begin{array}{c}\text { George I } \\
(1714-1727)\end{array}$} & $\begin{array}{l}\text { number of } \\
\text { finds }\end{array}$ & 37 & 53 & 8 & 2 & 1 & 12 & 15 & 5 \\
\hline & $\%$ of finds & $27.4 \%$ & $39.3 \%$ & $5.9 \%$ & $1.5 \%$ & $0.7 \%$ & $8.9 \%$ & $11.1 \%$ & $3.7 \%$ \\
\hline & $\begin{array}{c}\text { value of } \\
\text { finds (in } \mathscr{E})\end{array}$ & 9.25 & 26.5 & 8 & 4 & 6 & 1584 & 180 & 1260 \\
\hline & $\begin{array}{c}\text { value of } \\
\text { finds (in \% } \\
\text { of the total } \\
\text { value) }\end{array}$ & $0.3 \%$ & $0.9 \%$ & $0.3 \%$ & $0.1 \%$ & $0.2 \%$ & $51.3 \%$ & $5.8 \%$ & $40.8 \%$ \\
\hline \multirow{4}{*}{$\begin{array}{c}\text { George II } \\
(1727-1760)\end{array}$} & $\begin{array}{l}\text { number of } \\
\text { finds }\end{array}$ & 58 & 135 & 7 & 1 & 14 & 9 & 12 & O \\
\hline & $\%$ of finds & $24.5 \%$ & $57.0 \%$ & $3.0 \%$ & $0.4 \%$ & $5.9 \%$ & $3.8 \%$ & $5.1 \%$ & $0.0 \%$ \\
\hline & $\begin{array}{c}\text { value of } \\
\text { finds (in } £ \text { ) }\end{array}$ & 14.5 & 67.5 & 7 & 2 & 84 & 189 & 144 & O \\
\hline & $\begin{array}{c}\text { value of } \\
\text { finds (in \% } \\
\text { of the total } \\
\text { value) }\end{array}$ & $2.8 \%$ & $13.2 \%$ & $1.4 \%$ & $0.4 \%$ & $16.5 \%$ & $37.0 \%$ & $28.2 \%$ & $0.0 \%$ \\
\hline \multirow{4}{*}{$\begin{array}{c}\text { George III } \\
(1760-1820)\end{array}$} & $\begin{array}{c}\text { number of } \\
\text { finds }\end{array}$ & 33 & 168 & 100 & 1 & 39 & 16 & 21 & 19 \\
\hline & $\%$ of finds & $7.7 \%$ & $39.4 \%$ & $23.5 \%$ & $0.2 \%$ & $9.2 \%$ & $3.8 \%$ & $4.9 \%$ & $4.5 \%$ \\
\hline & $\begin{array}{c}\text { value of } \\
\text { finds (in } £ \text { ) }\end{array}$ & 8.25 & 84 & 100 & 2 & 234 & 2112 & 252 & 4788 \\
\hline & $\begin{array}{c}\text { value of } \\
\text { finds (in \% } \\
\text { of the total } \\
\text { value) } \\
\end{array}$ & $0.1 \%$ & $1.0 \%$ & $1.2 \%$ & $0.0 \%$ & $2.8 \%$ & $25.1 \%$ & $3.0 \%$ & $56.8 \%$ \\
\hline
\end{tabular}




\section{Coin and credit: Intellectual and political debates}

Conventionally classified under the mercantilist umbrella, contemporary intellectuals such as Malynes, Miselden and Mun and their disciples, were unanimous that the scarcity of bullion was a problem, hence the emphasis on access to bullion under a favorable trade balance. ${ }^{51}$ In the case of Paterson, Godfrey and Mackworth, paper money was advocated as a solution, but always making clear that the extent of expansion was indirectly constrained by access to bullion. ${ }^{52}$

In fact, the common denominator of the mercantilist literature seems to have been the preoccupation with the capacity of money to encourage economic growth. Adam Smith was mistaken in accusing these mercantilists of confusing money with wealth, because in fact the limitations of credit expansion meant that "there was no other way to expand the money stock than to attract silver and gold from abroad" (Wennerlind 2011, p. 40)..$^{53}$

Wennerlind (2011) argues that restrictions on endogenous money creation were over once the law allowed the current holder of the debt instrument to sue the initial debtor. This is where my position differs. By itself, this would have been unable to support the subsequent eighteenth-century growth. As the end of the seventeenth century approached, the fall of the

${ }^{51}$ The state indeed often took action: legislation prohibited the export of bullion. In the non-cooperative world of medieval and early modern Europe, perhaps there was some rationale to these policies which were castigated by Adam Smith and other classical writers. Indeed, it is noticeable that "such bullionist legislation was a constant feature of the work of late medieval parliaments” (Mayhew 1974, p. 62)

${ }^{52}$ Other writers such as Hugh Chamberlen and John Briscoe advocated a national land bank, which would expand money based on the security of land, not bullion. The utter failure of the Land Bank United, launched in 1696, to attract capital (in sharp contrast to the Bank of England's oversubscribed issue two years earlier) suggests that this foundation was not possible. Only around the time of the restriction act (1797) was it really possible to have monetary expansion independent of bullion (O'Brien and Palma forthcoming), and as the establishment of the gold standard in 1821 suggests, even those measures were, for the time being, temporary.

${ }^{53}$ With regard to the issue of trade competiveness in connection with deflation, it is noticeable that, at times, it was explicitly recognized that in order for trade to remain completive, the right amount of money was needed to maintain the price level (Wennerlind 2011, p. 40). 
average silver content of coin to $50 \%$ of the official weight meant a serious monetary crisis, in part because silver coin served as security for the notes of the Bank of England (Wennerlind 2011, p.11). This suggests that, later on, the lack of gold would have presented an obstacle..$^{54}$

As contemporaries recognized, the feasibility of taking credit was all about reputation. Even though the lack of currency in the face of expanding commerce provided an incentive for the development of forms of inside money, these could only be sustained as long as merchants were convinced of the buyer's "Integrity and Ability for Payment", and more generally, the "honourable Performance of contracts and Covenants" (Defoe 1709). ${ }^{55}$ This was, in fact, representative of the position of the intellectual elite of the time. Even Wennerlind (2011, p. 241) recognizes that David Hume, while open to the notion that under appropriate levels of trust credit could flourish, insisted that currency based on silver and gold was "more practical." Adam Smith advocated a similar position. Inside money could be created, but it led to higher transaction costs. As modern theory suggests, "A shortage of liquidity induces the private sector to try and create more stores of value, albeit at a cost” (Holmström and Tirole $2011, \mathrm{p} 5) .{ }^{56}$

\footnotetext{
${ }^{54}$ Furthermore, in England the reformation created a huge concentration of wealth in England and hindered the development of a credit sector. That is why money may have been a greater bottleneck in England than in Southern Europe, and not only in Italy. In other Protestant countries such as the Netherlands, Italian banking and urban institutions were at times used to finance the gap. Thanks to Regina Grafe for help in clarifying this point.

${ }^{55}$ In an attempt to popularize the notion of credit (and defend his increasingly pro-Tory political position), Defoe used the rhetorical figure of "Lady credit", the younger sister of money, who could take her sister's role in trade, but only as long as "her Sister constantly and punctually relieves her" (Defone 1706). For a recent review of Defoe's role in popularizing the polices of Harley, see Wennerlind (2011, p. 181-189).

${ }^{56}$ In the American colonies, in particular in Virginia, Barbados and even Scotland, paper money was often used, but it only had the ability to circulate locally and under high transaction costs. Finally, one additional reason that the change to a fiat system did not happen earlier may have been related to the limited political influence of the groups that would gain from inconvertibility and depreciation (Eichengreen 1992).
} 


\section{Appendix references}

Challis (1992). A New History of the Royal Mint. Cambridge University Press

Defoe, D. (1706). Review of the State of the British Nation, January 10

Defoe, D. (1709). Review of the State of the British Nation, June 14

Eichengreen, B. (1992). Golden fetters: the gold standard and the Great Depression, 1919-1939. Oxford University Press. Chicago

Holmström, B., and Tirole, J. (2011). Inside and outside liquidity. MIT press

Mayhew, N. J. (1974). The Monetary Background to the Yorkist Recoinage of 1464-1471.

British Numismatic Journal

O'Brien, P. and Nuno Palma (forthcoming). Danger to the Old Lady of Threadneedle Street? The Bank Restriction Act and the regime shift to paper money, 1797-1821. European Review of Economic History

Wennerlind, Carl (2011). Casualties of Credit: The English Financial Revolution. Harvard University Press 